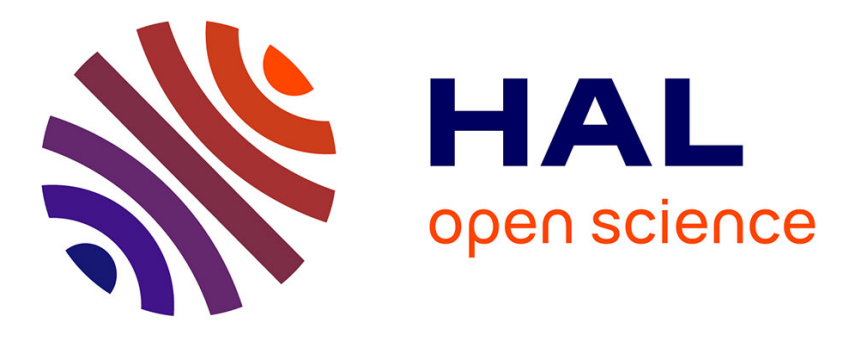

\title{
Eyjafjallajökull ash concentrations derived from both lidar and modeling
}

Patrick Chazette, Marc Bocquet, Philippe Royer, Victor Winiarek, Jean-Christophe Raut, Philippe Labazuy, Mathieu Gouhier, Mélody Lardier, Jean-Pierre Cariou

\section{To cite this version:}

Patrick Chazette, Marc Bocquet, Philippe Royer, Victor Winiarek, Jean-Christophe Raut, et al.. Eyjafjallajökull ash concentrations derived from both lidar and modeling. Journal of Geophysical Research: Atmospheres, 2012, 117, pp.D00U14. 10.1029/2011JD015755 . hal-00643869

\section{HAL Id: hal-00643869 https://hal.science/hal-00643869}

Submitted on 26 Nov 2013

HAL is a multi-disciplinary open access archive for the deposit and dissemination of scientific research documents, whether they are published or not. The documents may come from teaching and research institutions in France or abroad, or from public or private research centers.
L'archive ouverte pluridisciplinaire HAL, est destinée au dépôt et à la diffusion de documents scientifiques de niveau recherche, publiés ou non, émanant des établissements d'enseignement et de recherche français ou étrangers, des laboratoires publics ou privés. 


\title{
Eyjafjallajökull ash concentrations derived from both lidar and modeling
}

\author{
Patrick Chazette, ${ }^{1}$ Marc Bocquet, ${ }^{2,3}$ Philippe Royer, ${ }^{1,4}$ Victor Winiarek, ${ }^{2,3}$ \\ Jean-Christophe Raut, ${ }^{5}$ Philippe Labazuy, ${ }^{6}$ Mathieu Gouhier, ${ }^{6}$ Mélody Lardier, ${ }^{4}$ \\ and Jean-Pierre Cariou ${ }^{4}$ \\ Received 1 February 2011; revised 14 November 2011; accepted 16 November 2011; published 25 February 2012.
}

[1] Following the eruption of the Icelandic volcano Eyjafjallajökull on the 14 April 2010, ground-based $\mathrm{N}_{2}$-Raman lidar (GBL) measurements were used to trace the temporal evolution of the ash plume from 16 to 20 April 2010 above the southwestern suburb of Paris. The nighttime overpass of the Cloud-Aerosol LIdar with Orthogonal Polarization onboard Cloud-Aerosol Lidar and Infrared Pathfinder Satellite Observation satellite (CALIPSO/CALIOP) on 17 April 2010 was an opportunity to complement GBL observations. The plume shape retrieved from GBL has been used to assess the size range of the particles size. The lidar-derived aerosol mass concentrations (PM) have been compared with model-derived PM concentrations held in the Eulerian model Polair3D transport model, driven by a source term inferred from the SEVIRI sensor onboard Meteosat satellite. The consistency between model and ground-based wind lidar and CALIOP observations has been checked. The spatial and temporal structures of the ash plume as estimated by each instrument and by the Polair3D simulations are in agreement. The ash plume was associated with a mean aerosol optical thickness of $0.1 \pm 0.06$ and $0.055 \pm 0.053$ for GBL $(355 \mathrm{~nm})$ and CALIOP $(532 \mathrm{~nm})$, respectively. Such values correspond to ash mass concentrations of $\sim 400 \pm 160$ and $\sim 720 \pm 670 \mu \mathrm{g} \mathrm{m}^{-3}$, respectively, within the ash plume, which was lower than $0.5 \mathrm{~km}$ in width. The relative uncertainty is $\sim 75 \%$ and mainly due to the assessment of the specific cross-section assuming an aerosol density of $2.6 \mathrm{~g} \mathrm{~cm}^{-3}$. The simulated ash plume is smoother leading to integrated mass of the same order of magnitude (between 50 and $250 \mathrm{mg} \mathrm{m}^{-2}$ ).

Citation: Chazette, P., M. Bocquet, P. Royer, V. Winiarek, J.-C. Raut, P. Labazuy, M. Gouhier, M. Lardier, and J.-P. Cariou (2012), Eyjafjallajökull ash concentrations derived from both lidar and modeling, J. Geophys. Res., 117, D00U14, doi:10.1029/2011JD015755.

\section{Introduction}

[2] The eruption of the Icelandic volcano Eyjafjallajökull that occurred on April 2010 disrupted air traffic across western and northern Europe for several weeks. The impact of the volcanic ash on the air traffic had been previously described by Casadevall [1994]. About 100,000 flights were canceled, with losses reportedly totaling more than 4 billion Euros following this major crisis. Serious damage to aircraft engines were expected because of silica-rich ash $(>50 \%)$ suspended in the volcanic cloud.

\footnotetext{
${ }^{1}$ LSCE, CEA-CNRS-UVSQ, CEA Saclay, Gif-sur-Yvette, France.

${ }^{2}$ Université Paris-Est, CEREA, Joint Laboratory École des Ponts ParisTech and EDF R\&D, Champs-sur-Marne, France.

${ }^{3}$ INRIA, Paris Rocquencourt Research Centre, Le Chesnay, France. ${ }^{4}$ LEOSPHERE, Paris, France.

${ }^{5}$ LATMOS, UPMC-UVSQ-CNRS, Université Paris 6, Paris, France.

${ }^{6}$ OPGC/LMV, CNRS-IRD-UBP, Clermont-Ferrand, France.
}

[3] The first eruption of primitive basalt magma was on 20 March 2010 in a crater in Fimmvörduháls pass between the two central volcanoes, Eyjafjallajökull and Katla. This first phase was characterized by lava fountains up to $200 \mathrm{~m}$ height, together with active degassing and lava effusion. A few hours later, a seismic crisis began 20-25 km beneath the summit crater of Eyjafjallajökull, and a long eruptive fissure opened in the Eyjafjallajökull glacier with more silicic magma, first leading to large water flash floods, and mudflows northward to the volcano due to ice melting [Gudmundsson et al., 2010; Sigmundsson et al., 2010]. The main consequences were local; about 1000 farmers have been evacuated, as well as cattle and some inhabitants living in the ashfall area. This phreatomagmatic eruption was characterized by highly explosive phases due to magmawater interaction increasing the fragmentation of pyroclastic cinders. The activity of 14-15 April fed a dark-gray volcanic cloud of ash and gas that drifted eastward at an altitude between 8 and $10 \mathrm{~km}$, and caused the complete closure of European airspace. 
[4] Lidar systems have been used by the scientific community to observe recent major volcanic eruptions reaching the stratosphere. For instance, in France, a lidar system operated at the Observatoire de Haute Provence $\left(44^{\circ} \mathrm{N}, 5^{\circ} \mathrm{E}\right)$ [Chazette et al., 1995] followed the volcanic aerosol due to the El Chichon and Mont Pinatubo eruptions in 1982 and 1991, respectively. These lidar measurements were performed concurrently with those of McCormick and Veiga [1992] during the Mount Pinatubo event and Michalsky et al. [1984] during the El Chichon event. The stratospheric residence times of particles formed after the massive injection of gaseous precursors were determined from the lidar measurements.

[5] The Eyjafjallajökull eruption has only impacted the troposphere where ash and gas components have been injected up to $10 \mathrm{~km}$ above the mean sea level (amsl), close to the tropopause height [Labazuy et al., 2012; Sigmundsson et al., 2010]. Monitoring such an amount of aerosols was required together with the assessment of vertically resolved mass concentrations in the atmospheric column so as to meet the societal need. Flying inside the ash plume presents a lot of hardships, particularly due to the potential risks for aircraft engines. Moreover, the in situ sampling performed onboard the aircraft is partially representative due to the aerosol size range larger than several micrometers [Schumann et al., 2011; Flentje et al., 2010]. The lidar remote sensing measurement is thus an interesting alternative that could be considered as sustainable, but associated with strong uncertainties when deriving mass concentrations from optical parameters [Raut and Chazette, 2009]. Lidar can provide continuous observations. The knowledge of vertical profiles of ash mass concentrations, including the associated uncertainties, is a powerful constraint for aerosol transport models [Tombette et al., 2008].

[6] The article aims at presenting first results on the ash plume mass concentration assessment and its comparison with an Eulerian transport model. Section 2 presents the instrumental setup and section 3 presents the modeling tools. The lidar analysis in terms of mass concentrations is presented in section 4. The use of lidar as a constraint for modeling is described in section 5 .

\section{Instrumental Setup}

[7] Ultraviolet $(355 \mathrm{~nm})$ ground-based N2-Raman and Doppler WINDCUBE200 lidars working close to Paris have been used to retrieve the vertical profile of the ash plume required to constrain the Eulerian aerosol transport model. The ground-based AErosol RObotic NETwork (AERONET) sites of Paris and Palaiseau have been used to validate the aerosol optical thickness retrieved from the lidar located at Saclay $\left(48.73^{\circ} \mathrm{N}, 2.17^{\circ} \mathrm{E}, 180 \mathrm{~m}\right.$ amsl), close to Palaiseau, in the southwestern suburb of Paris. The volcano source has been characterized from SEVERI measurements in the infrared (IR) channel. The spaceborne Cloud-Aerosol LIdar with Orthogonal Polarization (CALIOP), onboard the Cloud-Aerosol Lidar Pathfinder Satellite Observation (CALIPSO), has also been used to infer aerosol optical properties at $532 \mathrm{~nm}$ and to check the consistency with the ground-based lidar.

\subsection{Ground-Based Lidars}

[8] The new nitrogen Raman (N2-Raman) lidar (N2LAUV) is a prototype developed by the Commissariat à l'Energie Atomique (CEA) and the LEOSPHERE Company [Royer et al., 2010a] emitting in the ultraviolet, and based on a pulsed Nd:YAG laser manufactured by QUANTEL operating at $355 \mathrm{~nm}$ with a pulse repetition rate of $20 \mathrm{~Hz}$. The emitted energy is $16 \mathrm{~mJ}$ per pulse. It is composed of two reception channels: one dedicated to the measurement of the two elastic cross-polarizations at $355 \mathrm{~nm}$ and a second one to the inelastic nitrogen Raman backscattered signal at $\sim 387 \mathrm{~nm}$. It is designed to monitor the aerosol dispersion in the low and middle troposphere. It enables the retrieval of aerosol optical properties (extinction, backscatter coefficient and depolarization ratio) and atmospheric structures (planetary boundary layer (PBL) heights, aerosol layers and clouds) with a spatial sampling of $1.5 \mathrm{~m}$ along the line of sight in analog mode, the vertical resolution is finally close to $15 \mathrm{~m} . \mathrm{N}_{2}$-LAUV is dedicated to air quality survey in urban environments. A compromise between instrument performance, a high mobility and a low full-overlap function has been reached for air quality studies. The low laser energy combined with the $15 \mathrm{~cm}$ diameter telescope enable to obtain a compact $(\sim 70 \times 45 \times 18 \mathrm{~cm})$ and light $(<50 \mathrm{~kg}$ for optical and electronic) system operating onboard the ground based Mobile Aerosol Station (MAS) in a small truck [Chazette et al., 2005a; Raut and Chazette, 2007]. A wide field-of-view (FOV) $\sim 2.3 \mathrm{mrad}$ (4 mrad) enables reaching of a full-overlap beyond $\sim 200 \mathrm{~m}(100 \mathrm{~m})$ as shown in Figure 1 for the elastic (inelastic) channel. The main characteristics are given in Table 1.

[9] The lidar signal $S_{E}^{/ /(\perp)}$ derived from the parallel (perpendicular) channels is given by

$$
S_{E}^{/ /(\perp)}(z)=C_{E}^{/ /(\perp)} \cdot \beta^{/ /(\perp)}(z) \cdot \mathrm{T}(z)^{2}
$$

where $C_{E}^{/ /(\perp)}$ is the instrumental constant for channel parallel (perpendicular). $\mathrm{T}$ is the atmospheric transmission between the emitter and the sounded atmospheric layer at altitude $z$.

[10] The cross-calibration coefficient $C_{E}^{\| /} / C_{E}^{\perp}$ of the copolar and cross-polar channels has been assessed using normalization within a molecular zone between 4 and $4.5 \mathrm{~km}$ above the mean sea level (amsl) when only Rayleigh scattering occurred over Paris area. The mean relative uncertainty on the cross-calibration coefficient is $\sim 7 \%$. At the beginning of the event, when ash plume is present at these altitudes, the nearest significant cross-calibration coefficient is chosen. The molecular volume depolarization ratio $\left(V D R_{m}\right)$ has been taken equal to $0.3945 \%$ at $355 \mathrm{~nm}$ following Collis and Russell [1976] for Cabannes scattering, which is the only one occurring within the spectral width of the interferential filter.

[11] Hence, the total elastic lidar signal can be retrieved using the relation

$$
S_{E}(z) \equiv S_{E}^{\prime \prime}(z) \cdot(1+V D R(z))
$$




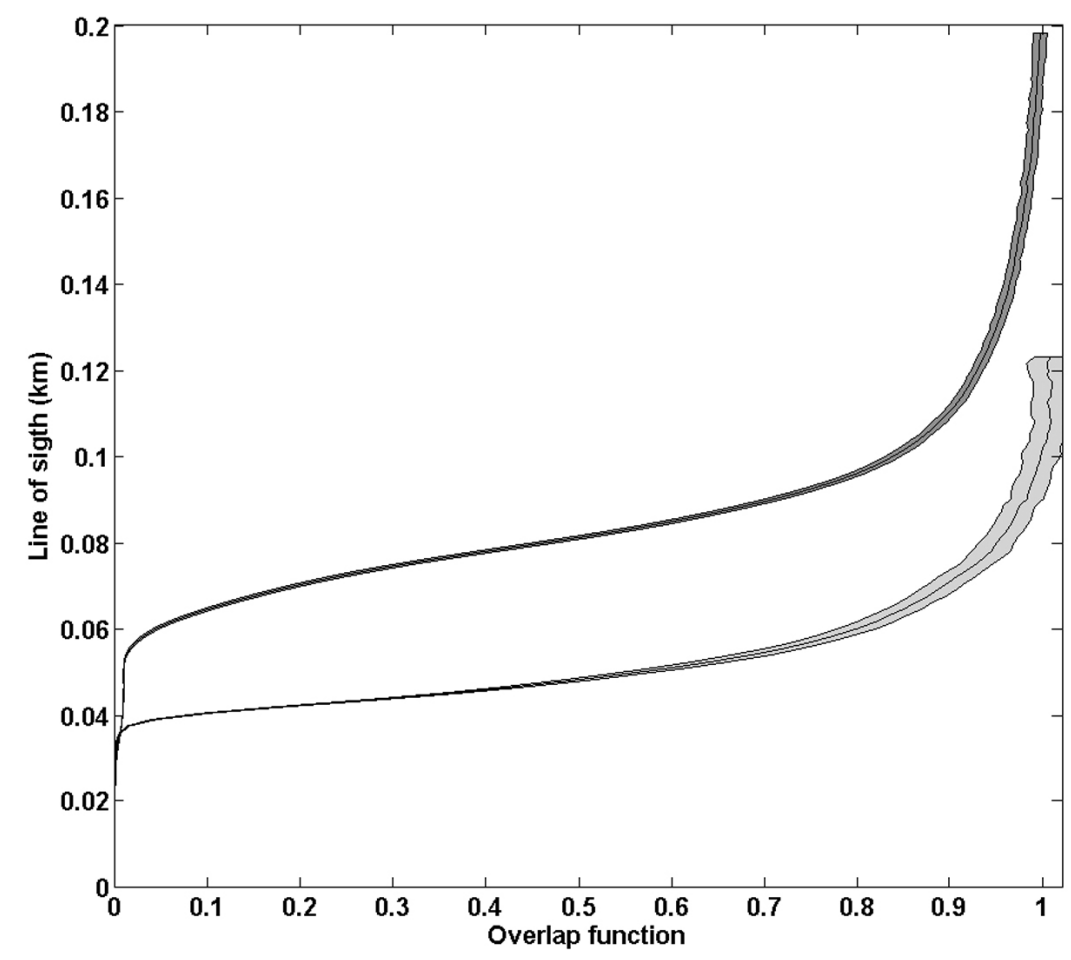

Figure 1. Overlap functions of the $\mathrm{N}_{2}$-LAUV lidar system for the elastic channel in clear gray and the inelastic channel in dark gray. Dark and light gray shaded areas show the uncertainty around the mean values.

where $V D R$ is the volume depolarization ratio

$$
V D R(z)=\frac{C_{E}^{\prime /}}{C_{E}^{\perp}} \cdot \frac{S_{E}^{\perp}(z)}{S_{E}^{/ /}(z)} .
$$

[12] The WINDCUBE200 is a commercial long range wind lidar developed and manufactured by LEOSPHERE for meteorological applications (Table 2). It is based on a

Table 1. Main Characteristic of the $\mathrm{N}_{2}$-LAUV Lidar System

\begin{tabular}{|c|c|}
\hline Characteristics & Details \\
\hline Detection system & $\begin{array}{c}\text { Analog mode PXi technology } \\
\text { at } 100 \mathrm{MHz}\end{array}$ \\
\hline Lidar head size & $\sim 70 \times 45 \times 18 \mathrm{~cm}^{3}$ \\
\hline Lidar head and electronic weight & $<50 \mathrm{~kg}$ \\
\hline Vertical sampling (resolution) & $1.5(15 \mathrm{~m})$ \\
\hline \multicolumn{2}{|c|}{ Emission } \\
\hline Laser & Nd:Yag Ultra (QUANTEL) \\
\hline Laser divergence & $0.1 \mathrm{mrad}$ \\
\hline Laser pulse length & $6-7 \mathrm{~ns}$ \\
\hline Energy & $16 \mathrm{~mJ}$ at $355 \mathrm{~nm}$ \\
\hline Frequency & $20 \mathrm{~Hz}$ \\
\hline \multicolumn{2}{|c|}{ Reception } \\
\hline Reception channels & $\begin{array}{c}\text { Elastic // } 355 \mathrm{~nm} \text { Elastic } \perp 355 \mathrm{~nm} \text {, } \\
\text { Raman- } \mathrm{N}_{2} 387 \mathrm{~nm}\end{array}$ \\
\hline Reception diameters & $15 \mathrm{~cm}$ \\
\hline Field of view & $2.3 \mathrm{mrad}, 4 \mathrm{mrad}$ \\
\hline Detector & Photomultiplier tubes \\
\hline Filter bandwidth & $0.3 \mathrm{~nm}$ \\
\hline
\end{tabular}

pulsed Erbium Doped Fiber Laser emitting at $1543 \mathrm{~nm}$, an all fiber optical architecture and a coherent detection for Doppler analysis. The lidar measures and displays in real time the relative backscattering coefficient for each altitude, as well as the wind direction and horizontal and vertical wind components. Wind components are retrieved thanks to 4 successive lines of sight along a cone. The maximum range exceeds $10 \mathrm{~km}$ on clouds and reaches the PBL height when natural or anthropogenic aerosols are present. The vertical resolution is $50 \mathrm{~m}$. The lidar is embedded in a IP65 compact casing $\left(80 \times 55 \times 55 \mathrm{~cm}^{3}\right)$ with storage and

Table 2. Main Characteristics of the WINDCUBE200 Doppler Lidar System

\begin{tabular}{ll}
\hline \multicolumn{1}{c}{ Characteristics } & \multicolumn{1}{c}{ Details } \\
\hline Laser & $\begin{array}{c}\text { Master Oscillator +Erbium Doped } \\
\text { Fiber Amplifier }\end{array}$ \\
Wavelength & $1543 \mathrm{~nm}$ \\
Pulse duration & $400 \mathrm{~ns}$ \\
Reception aperture & $100 \mathrm{~mm}$ \\
Cone angle & $15^{\circ}$ \\
Measurement update frequency & $10 \mathrm{~s}$ for all altitudes, 10 min averages \\
Range & $0-12 \mathrm{~km}$ on clouds, $0-6 \mathrm{~km}$ on \\
& aerosols \\
Range resolution & $50 \mathrm{~m}$ \\
Velocity range & -60 to $+60 \mathrm{~m}^{-1}$ \\
Velocity resolution & $0.3 \mathrm{~ms}$ \\
Outputs & $\mathrm{u}, \mathrm{v}, \mathrm{w}$ D wind components, relative \\
& backscattering coefficient, CNR \\
Lidar total size & $80 \times 55 \times 65 \mathrm{~cm}^{3}$ \\
Weight & $70 \mathrm{~kg}$ \\
Environment & $-30^{\circ} \mathrm{C}$ to $+50^{\circ} \mathrm{C}$, IP65. \\
\hline
\end{tabular}


communication devices, allowing autonomous atmospheric surveys during long periods. The precision on the wind speed measurement is $\sim 0.3 \mathrm{~ms}^{-1}$.

\subsection{Sunphotometer}

[13] A CIMEL $®$ sunphotometer instrument performs integrated measurements of solar light absorption, in order to retrieve the aerosol optical thickness (AOT) at several wavelengths and the Angstrom exponent at Aerosol Robotic Network (AERONET) sites of Paris and Palaiseau. The channels used for this study are centered at 340 and $380 \mathrm{~nm}$ on both sides of the emitted ultraviolet lidar wavelength. The channels have spectral bandwidths lower than $20 \mathrm{~nm}$. The instrument field of view is about $1^{\circ}$ [e.g., Holben et al., 1998]. Optical thickness data are available on the Web site http://aeronet.gsfc.nasa.gov/ after inversion with the procedure used in AERONET. The AERONET database gives a maximal absolute uncertainty of 0.02 for the optical thickness, which is wavelength dependent, due to calibration uncertainty of the field instruments. The uncertainty in the Angstrom exponent has been shown to be $\sim 0.03$ for an AOT of $\sim 0.2$ [Hamonou et al., 1999].

\subsection{Spaceborne Lidar CALIOP Onboard CALIPSO}

[14] The CALIOP transmitter onboard the CALIPSO satellite emits polarized light at both 1064 and $532 \mathrm{~nm}$ with pulse energy of $110 \mathrm{~mJ}$ and a pulse repetition rate of 20.25 Hz. Polarization discrimination in the receiver is performed for the $532 \mathrm{~nm}$ channel [Winker et al., 2004, 2007; Hunt et al., 2009]. Details on the CALIOP instrument, data acquisition, and science products are given by Anselmo et al. [2005] and Winker et al. [2007]. In this work, we use CALIOP data below $8 \mathrm{~km}$ amsl at the wavelength of $532 \mathrm{~nm}$ during nighttime. The sensitivity to capture aerosol features is better in the visible channel than in the infrared channel at $1064 \mathrm{~nm}$ owing to a better signal-to-noise ratio (SNR). The CALIOP level-1 (version 3.01) products are only considered because level-2 data were not available at the beginning of this work. Level-1 data have been inverted using an approach well described in detail by Chazette et al. [2010] and by Royer et al. [2010b]. CALIOP level-1 data have different spatial resolutions depending on the altitude ranges. Between 0.5 and $8.2 \mathrm{~km}$ amsl the spatial resolution is $\Delta \mathrm{z}=$ $30 \mathrm{~m}$ vertically and $\Delta \mathrm{x}=333 \mathrm{~m}$ horizontally.

[15] The $532 \mathrm{~nm}$ calibration constant corresponding to the nighttime portion of the orbits is determined for every $55-\mathrm{km}$ average profile (11 frames) by comparing the 532-parallel polarization signal in the $30-34 \mathrm{~km}$ altitude range to a scattering model value derived from molecular and ozone number densities provided by NASA's Global Modeling and Assimilation Office (GMAO). A constant value of the calibration constant is applied to all single-shot profiles in each $55-\mathrm{km}$ averaging region after an additional smoothing operation applied to the values retrieved at $55-\mathrm{km}$ intervals [Hostetler et al., 2005; Powell et al., 2009].

\subsection{SEVIRI Onboard Meteosat}

[16] The SEVIRI sensor (Spinning Enhanced Visible and InfraRed Imager) onboard Meteosat Second Generation (MSG) operates at a very high temporal resolution up to one image every $5 \mathrm{~min}$ with a spatial resolution up to $1 \mathrm{~km}^{2}$ and using 12 channels ranging from the visible to the infrared.
MSG-SEVIRI sensor hence turns out to be a valuable tool for the tracking of volcanic ash clouds and for the quantitative assessment of their properties [Prata and Kerkmann, 2007]. Volcanic ash can be clearly distinguished from nonvolcanic atmospheric clouds using a Brightness Temperature Difference method (BTD) based on the differential extinction features of ash between 11 and $12 \mu \mathrm{m}$ channels [Prata, 1989]. This permits to qualitatively describe the horizontal structure of the ash cloud, and allows the real-time monitoring of the ash cloud dispersion. Inversion of the MSGSEVIRI data based on look-up table algorithm [Wen and Rose, 1994] can also be used to provide quantitative estimates of essential parameters such as ash concentration and radius, as well as cloud height. However, this requires assumptions on scattering properties and size distribution of particles. Moreover, this method only describes the mass concentration integrated on a 2-D horizontal plane.

\section{Modeling}

\subsection{Description}

[17] The simulations of the ash plume have been carried out with the Eulerian chemistry and transport model Polair3D, part of the POLYPHEMUS platform. In particular, this air quality model has been validated for accidental dispersion at continental scale on the ETEX-I, Algeciras and Chernobyl events [Quélo et al., 2007], as well as for tracer inverse modeling [e.g., Davoine and Bocquet, 2007].

[18] The domain simulation is $\left[25^{\circ} \mathrm{W}, 30^{\circ} \mathrm{E}\right] \times\left[40^{\circ} \mathrm{N}\right.$, $\left.73^{\circ} \mathrm{N}\right]$ encompassing most of western and central Europe, and Iceland. This domain suits the plume dispersion originating from the first eruption of 14 April 2010. The horizontal resolution is $0.5^{\circ} \times 0.5^{\circ}$. We have considered as many as 35 levels because of the elevated ash injection heights. Those levels are $0 \mathrm{~m}, 50 \mathrm{~m}, 120 \mathrm{~m}, 250 \mathrm{~m}, 500 \mathrm{~m}$, and then from $1000 \mathrm{~m}$ to $16000 \mathrm{~m}$, one level every $500 \mathrm{~m}$. The wind fields and other meteorological fields have been obtained or diagnosed from the European Centre for Medium-Range Weather Forecasts (ECMWF) fields for the period (http://www.ecmwf.int/ research/ifsdocs/CY36r1/ index.html).

[19] The numerical scheme for advection is a direct spacetime third-order scheme with a van Leer flux-limiter. The diffusion scheme is a space three-point scheme for each direction, integrated in time thanks to a second-order Rosenbrock method. Horizontal spatial diffusion is neglected while the turbulent vertical diffusivity is parameterized using the Troen and Mahrt scheme [Troen and Mahrt, 1986]. Wet scavenging is not considered here, since there was no significant rainfall recorded for the first eruption period over Western Europe. Dry deposition is not accounted for either since we shall consider that it is taken over by the sedimentation in the lowest level.

[20] A critical issue is the vertical ashfall speed, and how it should be parameterized in the model [Niemeier et al., 2009]. Following Searcy et al. [1998], the fallout rate is chosen to be given by the terminal velocity from the Stokes law. The equation (16) of Chazette et al. [1995] that includes a slip correction factor has been used. The effect of this correction may be non-negligible given that a wide range of altitude is explored and given that particles smaller than $10 \mu \mathrm{m}$ are also under scrutiny. 
Table 3. Daily Average Estimate of the Atmospheric Ash Mass Flux Derived From MSG-SEVIRI

\begin{tabular}{cccccccccccc}
\hline & $14 \mathrm{Apr}$ & $15 \mathrm{Apr}$ & $16 \mathrm{Apr}$ & $17 \mathrm{Apr}$ & $18 \mathrm{Apr}$ & $19 \mathrm{Apr}$ & $20 \mathrm{Apr}$ & $21 \mathrm{Apr}$ & $22 \mathrm{Apr}$ & $23 \mathrm{Apr}$ & $24 \mathrm{Apr}$ \\
\hline Ash flux (t/s) & $0.2 \pm 0.025$ & $2.5 \pm 0.3$ & $0.5 \pm 0.06$ & $0.65 \pm 0.08$ & $0.4 \pm 0.05$ & $4.25 \pm 0.5$ & $1 \pm 0.1$ & $0.05 \pm 0.006$ & 0 & $0.33 \pm 0.04$ & $0.23 \pm 0.03$ \\
\hline
\end{tabular}

[21] The main source of uncertainties in the forecast of volcanic ash appears to be the initialization phase of the atmospheric dispersion models at the vicinity of the source, and then the assessment of the source terms in term of mass concentration fluxes.

\subsection{Source Term Derived From Satellite Data}

[22] For many years it has been well known that weather satellite data can provide a means for mapping and tracking volcanic ash by virtue of its characteristic signal in the thermal infrared $(10.8-12 \mu \mathrm{m})$ such as MODIS and Advanced Very High Resolution Radiometer (AVHRR). However, new sensors onboard geostationary satellites such as MSG-SEVIRI, which also provides data in the IR, now allow volcanic clouds to be tracked, and their ash content quantified every $15 \mathrm{~min}$ in near-real-time. This has increased our ability to provide precise input for model based simulations and hazard assessment.

[23] From April 14 2010, we began on-reception processing of all Meteosat images, and we completed the inversion of the MSG-SEVIRI infrared data using the forward model developed by Wen and Rose [1994] to estimate the mass flux of ash released in the atmosphere with an error of about 10$15 \%$ (Table 3 ). This method is based on the differential extinction features of volcanic aerosols at different wavelengths. Prata [1989] has shown that the negative Brightness Temperature Difference (BTD) between the 11 and $12 \mu \mathrm{m}$ channels permits the discrimination of ash among various species (e.g., water droplets, ice crystals) in the volcanic cloud. Hence, modeling the synthetic BTD provides a first order estimate of ash mass and concentration inside the cloud. The mass flux derived from this method represents the amount of fine ash $(<10-20 \mu \mathrm{m}$ in diameter) released in the atmosphere, far from the volcanic vent. This method has been used on a series of explosive eruptions through the last decade, and validated from ground-based remote sensing measurements as well as from ground deposit studies. However, the detection threshold of this method is directly related to the wavelengths (IR) of the sensor, which hardly allows the detection of submicronic volcanic ash. On the contrary, Mie scattering theory will only permit us to retrieve maximum ash particle sizes, which order of magnitude is close to the wavelengths of the sensor. This effect is much more complex to assess, but overall, it may overestimate the total amount of ash in the cloud.

[24] The source flux of ash emissions called "total tephra" close to the vent can be roughly estimated from empirical relations. Indeed, Wen and Rose [1994] have shown that the mass released in the atmosphere may represent about $0.5 \%$ to $1 \%$ of the total tephra. This range can be used as minimum and maximum values representing an error margin of a factor of 2 for the estimate of source ash flux emissions.

[25] The altitude of the plume can be retrieved using various methods, each having their own uncertainties. The CTT (Cloud Top Temperature) method is the most common one, and derives the cloud top altitude using the $10.8 \mu \mathrm{m}$ radiance channel, assuming that the ash cloud is totally opaque and in thermal equilibrium with the atmosphere. However, the ash cloud often being not totally optically thick, this method leads to an underestimate of the cloud top altitude. In the case of Eyjafjallajökull eruption, many aircraft and radar measurements have been carried out close to the eruptive site, and have provided undoubtedly the most reliable data set of plume altitude. The VAAC (Volcanic Ash Advisory Centre) of London has used and summarized all these data (http://www.metoffice.gov.uk/aviation/vaac/index.html).

Figure 2 shows the altitude of the ash plume above the crater during the first few days (14-22 April 2010) after the onset of the Eyjafjallajökull eruption. Error margins reported in the figure correspond to the variation of the ash plume altitude during the day. The maximum height of about $10 \mathrm{~km}$ is reached at the onset of the eruption on 14 April. The average altitude of the plume then progressively decreases until 22 April with a minimum height of $4 \mathrm{~km}$ being reported on 21 April 2010.

[26] For modeling purposes, the mass concentration calculated from the daily average of the ash mass flux (Table 3) is supposed to be uniformly spread over the error bar of the average ash plume height.

\section{Lidar Analysis in Terms of Mass Concentration}

[27] Rayleigh-Mie lidar measurements have provided two types of information. The first one is relative to the vertical structure of the atmosphere, i.e., the altitude of the scattering layer, and the second one concerns the vertical profile of the aerosol optical properties, i.e., the aerosol extinction and backscatter coefficients. The aerosol mass concentration

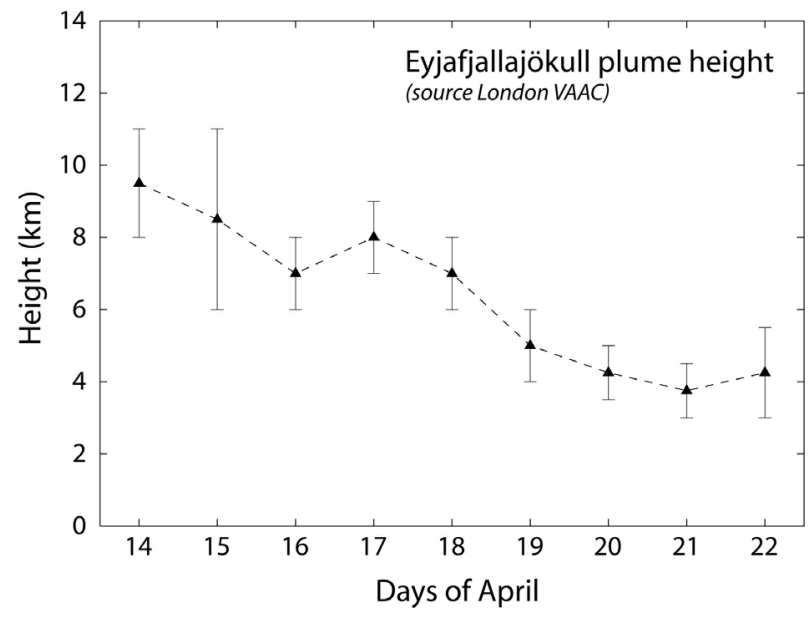

Figure 2. Daily average of the volcanic plume altitude following VAAC (http://www.metoffice.gov.uk/aviation/vaac/ index.html). Error bars reported in the plot correspond to the variation of the ash plume altitude during the day. 


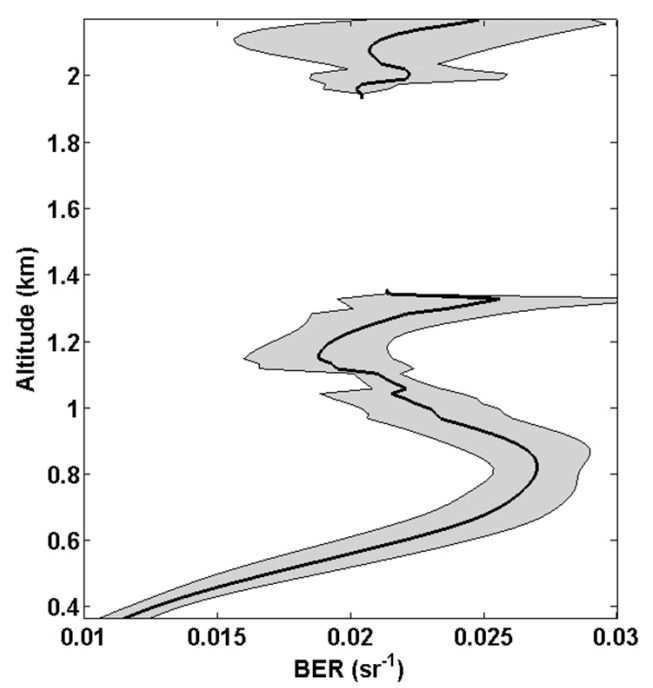

Figure 3. Mean profile of the BER retrieved from the $\mathrm{N}_{2}$ Raman lidar during the night of 17-18 April 2010. The gray area represents the temporal variability of BER.

(PM) cannot be directly assessed. Hence, this study has been performed in several steps: 1) retrieve the aerosol optical properties in terms of extinction coefficient using the $\mathrm{N}_{2}$ Raman measurements during nighttime and combine sunphotometer and lidar measurements during daytime to check the capability to temporally generalize the $\mathrm{N}_{2}$-Raman information; 2) assess the aerosol size distribution (ASD) using available airborne and sunphotometer measurements; 3 ) find realistic aerosol complex refractive index (ACRI) and aerosol density from previous studies; 4) assess the specific cross-section using the constraint provided by the lidar measurements; 5) and finally assess PM within the ash plume.

\subsection{Aerosol Extinction Coefficient}

[28] The range corrected lidar signals at the wavelength $\lambda_{E}$ and $\lambda_{R}$ for the elastic $S_{E}$ and inelastic $S_{R}$ channels is given at the altitude $z$ by [Measures, 1984] for each channel. The Angstrom exponent $A$ is close to 1.2 in the visible domain during the ash event over Paris following AERONET database. The mean Raman differential backscatter cross section $\sigma_{N 2}^{\pi}$ is $2.810^{-30} \mathrm{~cm}^{2} \mathrm{sr}^{-1}$ and the nitrogen density profile $n_{N 2}$ is derived from the previous climatological profiles. The ground-based altitude $z_{G}$ is close to $0.18 \mathrm{~km}$.

[30] Raman lidar measurements have been only inverted during nighttime due to both the altitude of the ash plume (over $2 \mathrm{~km}$ amsl) and the low signal-to-noise ratio of the Raman channel above $1 \mathrm{~km}$ amsl during daytime. Nevertheless, this provided the value of the backscatter to extinction ratio (BER) required to invert the elastic channel using the Klett [1985] algorithm [e.g., Chazette et al., 2005b; Kim et al., 2008].

[31] BER (inverse of the lidar ratio $L R$ ) retrieval uses the Tikhonov regularization method [Tikhonov and Arsenin, 1977]. It is well described by Royer et al. [2010a] where the uncertainty sources are discussed in detail. The mean BER profile and its variability retrieved from the N2-Raman lidar is given in Figure 3 for the night of 17-18 April 2010. It is very similar within the aerosol layers with $B E R=0.0215$ $\pm 0.0022 \mathrm{sr}^{-1}(L R=46.5 \pm 5 \mathrm{sr})$ and $B E R=0.0219 \pm$ $0.0035 \mathrm{sr}^{-1}$ for PBL and the ash plume, respectively. The corresponding uncertainties on BER values were calculated considering the highest aerosol extinction coefficients. They were found close to $0.003 \mathrm{sr}^{-1}$ [Royer et al., 2010a]. The LR in the ash plume retrieved in this study is close to LR values of $50 \pm 5$ and $60 \pm 5 \mathrm{sr}$ assessed by Ansmann et al. [2010] for Munich and Leipzig, respectively.

[32] Knowing BER, the elastic equation can be inverted where $\alpha_{a}$ is the solution of a Bernoulli first order differential equation given by

$$
\begin{aligned}
\alpha_{a}^{E}(z)= & B E R^{-1} \\
& \cdot\left(\frac{S_{E}(z) Q(z)}{\frac{S_{E}\left(z_{r}\right)}{\left(\beta_{m}^{E}\left(z_{r}\right)+\beta_{a}^{E}\left(z_{r}\right)\right)}+2 \cdot B E R^{-1} \int_{z}^{z_{r}} S_{E}\left(z^{\prime}\right) Q\left(z^{\prime}\right) d z^{\prime}}-\beta_{m}^{E}(z)\right)
\end{aligned}
$$

$$
\left\{\begin{array}{l}
S_{E}(z)=C_{E} \cdot\left(\beta_{m}^{E}(z)+\beta_{a}^{E}(z)\right) \cdot \exp \left(\frac{-2}{\cos (\theta)} \int_{z_{G}}^{z}\left(\alpha_{m}^{E}\left(z^{\prime}\right)+\alpha_{a}^{E}\left(z^{\prime}\right)\right) \cdot d z^{\prime}\right) \\
S_{R}(z)=C_{R} n_{N 2}(z) \cdot \sigma_{N 2}^{\pi} \exp \left(\frac{-1}{\cos (\theta)} \int_{z_{G}}^{z}\left[\alpha_{m}^{E}\left(z^{\prime}\right)\left(1+\left(\frac{\lambda_{R}}{\lambda_{E}}\right)^{-4.09}\right)+\alpha_{a}^{E}\left(z^{\prime}\right)\left(1+\left(\frac{\lambda_{R}}{\lambda_{E}}\right)^{-A}\right)\right] d z^{\prime}\right)
\end{array}\right.
$$

[29] The subscripts $E$ and $R$ stand for the elastic and the Raman channels, respectively. The molecular (resp. aerosol) contribution is characterized by both the extinction $\alpha_{m}$ (resp. $\alpha_{a}$ ) and the backscatter coefficients $\beta_{m}$ (resp. $\beta_{a}$ ). The molecular contribution has been calculated from climatological atmospheric density profiles from a climatological database of radiosoundings using the polynomial approximation proposed by Nicolet [1984]. The pointing angle $\theta$ is equal to 0 because only zenithal lidar measurements have been performed. $C_{E}$ and $C_{R}$ are the instrumental constants
[33] The reference altitude $z_{r}$ has been chosen between 6.6 and $7 \mathrm{~km}$ amsl where only molecular scattering occurred. $Q$ is the correction related to the differential molecular optical thickness calculated from the vertical profile of the molecular scattering coefficient:

$$
Q(z)=\exp \left(2\left[k_{f} \frac{3}{8 \pi \cdot B E R}-1\right] \int_{z}^{z_{r}} \alpha_{m}^{E}\left(z^{\prime}\right) d z^{\prime}\right)
$$

where $k_{f}$ is the King factor of air [King, 1923]. Considering $k_{f}=1$ leads to an overestimation on the molecular volume 
(a)
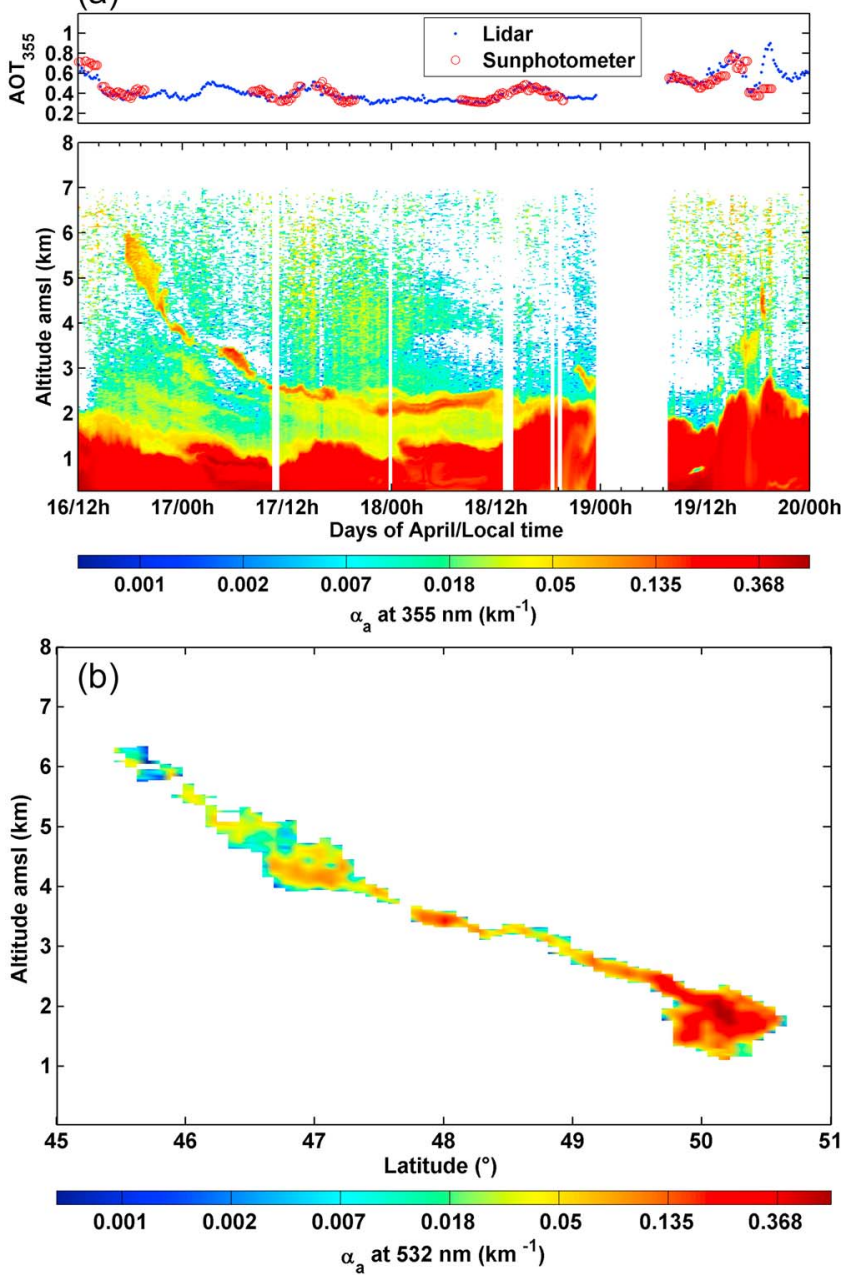

Figure 4. (a) (top) AOT at $355 \mathrm{~nm}$ derived from sunphotometer (red circles) and lidar measurements (blue points). (bottom) The temporal evolution of the vertical profile of the aerosol extinction coefficient $\left(\alpha_{a}\right)$ derived from GBL at $355 \mathrm{~nm}$. (b) The spatial evolution of the vertical profile of the aerosol extinction coefficient derived from CALIOP at $532 \mathrm{~nm}$ on 17 April. The CALIPSO/CALIOP transect begins at $\left(7.0749^{\circ} \mathrm{E}, 54.9998^{\circ} \mathrm{N}, 02: 05 \mathrm{UTC}\right)$ and ends at $\left(1.7726^{\circ} \mathrm{E}, 42.001^{\circ} \mathrm{N}, 02: 09 \mathrm{UTC}\right)$.

backscatter coefficient of only $1.5 \%$ at $355 \mathrm{~nm}$ [Collis and Russell, 1976]. Otherwise, uncertainties in the determination of $\alpha_{a}$ can be related to four main sources: (i) the statistical fluctuations of the measured signal, associated with random detection processes, (ii) the uncertainty on the lidar signal in the altitude range used for the normalization, (iii) the uncertainty on the a priori knowledge of the vertical profile of the Rayleigh backscatter coefficient as determined from ancillary measurements, (iv) the uncertainty on BER and on its altitude dependence. These different sources of uncertainty have been discussed by Chazette et al. [2010] and lead to an absolute error close to $0.01 \mathrm{~km}^{-1}$ on $\alpha_{a}$. Due to the distance between the emitter and the scattering layer, to the field of view, and to the AOT value (see below), the multiple scattering effect can be neglected in comparison to the other sources of uncertainty for the ground-based lidar
(GBL). It may affect the N2-Raman channel but this has not been assessed here.

[34] CALIPSO/CALIOP nighttime profiles of orbit 21112 on 17 April 2010 have been inverted using the same approach to the one described by Chazette et al. [2010] and Royer et al. [2010b]. The inversion is performed with a Klett forward algorithm using BER retrieved from the CALIOP level-2 data available within the volcanic ash plume $(B E R=$ $0.025 \mathrm{sr}^{-1}$ ). The aerosol extinction coefficient (AEC) at $532 \mathrm{~nm}$ can thus be retrieved within an absolute error of $0.03 \mathrm{~km}^{-1}$. This error increases when accounting for the multiple scattering effect due to large aerosol. Berthier et al. [2006] showed a $10 \%$ increase in BER values leading here to an additional error of $\sim 0.02 \mathrm{~km}^{-1}$ on AEC.

[35] AEC profiles derived from ground-based and CALIOP lidar are given in Figure 4. The specific shape of the ash plume can be observed on both GBL and CALIOP AEC profiles. The ash plume arrived above Paris on 16 April at 17:00 local time (LT) between 5 and $6 \mathrm{~km}$ amsl. Its altitude decreases to reach about $2 \mathrm{~km}$ amsl at midnight the 18 April. The mean $\alpha_{\alpha}^{E}$ within the ash plume are $0.1 \pm$ $0.06 \mathrm{~km}^{-1}$ and $0.055 \pm 0.053 \mathrm{~km}^{-1}$ for GBL $(355 \mathrm{~nm})$ and CALIOP $(532 \mathrm{~nm})$, respectively. The temporal evolutions of AOT at $355 \mathrm{~nm}$ derived from the GBL and sunphotometer are also given. The values are in very good agreement within an absolute difference of 0.02 , which is of the same order of the uncertainty on AOT sunphotometer measurement. The main differences are due to the presence of clouds. This gives a good level of confidence in the GBL inverted profiles.

[36] The temporal (resp. spatial) evolution of the volume depolarization ratio (VDR, ratio of the cross-polar to copolar channels) derived from GBL (resp. CALIOP) is given in Figure 5. The white bands correspond to the period where GBL was turned off. For the GBL, the result can be affected by the narrow filter bandwidth of $0.3 \mathrm{~nm}$ and a residual polarization may exist at the laser emission. Hence, VDR has to be considered as qualitative information. Note that the absolute error on VDR due to the one on the cross calibration coefficient is close to $2 \%$ within the ash plume and does not significantly affect AEC. These previous error sources have been corrected for the CALIOP instrument [Hostetler et al., 2005]. The mean VDR within the ash plume is close to $\sim 5.8 \pm 2.5 \%$ and $18 \pm 7 \%$ for GBL $(355 \mathrm{~nm})$ and CALIOP $(532 \mathrm{~nm})$, respectively. For the calculation, only data of latitude below $49.5^{\circ}$ and with AEC $>0.1 \mathrm{~km}^{-1}$ were considered so as to only take into account cloud-free data points with significant signal-to-noise ratio. Due to a higher contribution of the molecular scattering at $355 \mathrm{~nm}$, those values cannot be directly compared. The molecular contribution has consequently been removed to retrieve the particulate depolarization ratio $(P D R)$ :

$$
\begin{aligned}
& \operatorname{PDR}(z) \\
& \quad=\frac{\beta_{m}^{E}(z) \cdot\left(V D R_{m}-V D R(z)\right)-\beta_{a}^{E}(z) \cdot V D R(z) \cdot\left(1+V D R_{m}\right)}{\beta_{m}^{E}(z) \cdot\left(V D R(z)-V D R_{m}\right)-\beta_{a}^{E}(z) \cdot\left(1+V D R_{m}\right)},
\end{aligned}
$$

assuming that the scattering due to the ash plumes is spectrally neutral with a mean AEC between 0.1 and $0.16 \mathrm{~km}^{-1}$. Hence the mean value of PDR derived from GBL is between 8 and $37.6 \%$ and comparable to the one derived from 
(a)
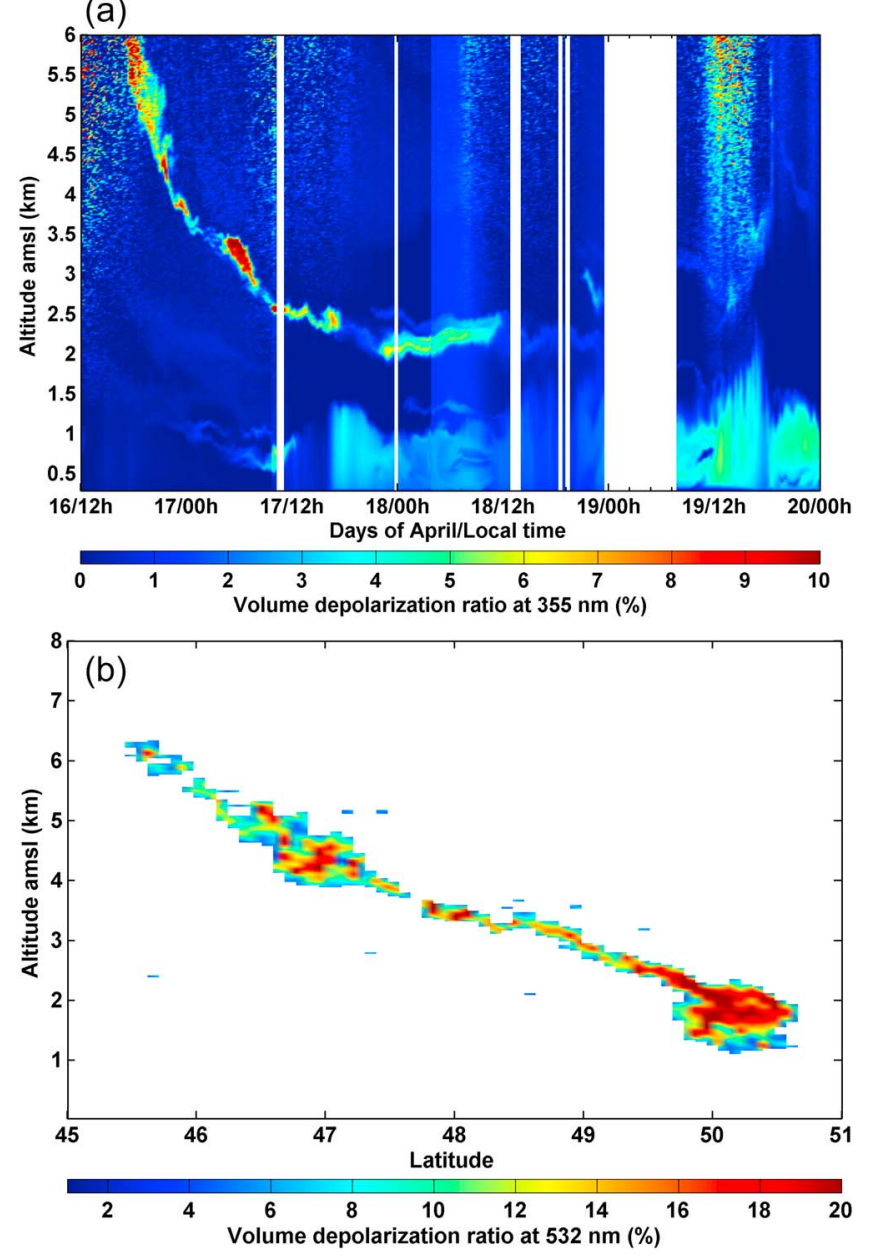

Figure 5. (a) The temporal evolution of the volume depolarization ratio vertical profile derived from GBL at $355 \mathrm{~nm}$. (b) The spatial evolution of the volume depolarization ratio vertical profile derived from CALIOP at $532 \mathrm{~nm}$ on 17 April. The CALIPSO/CALIOP transect begins at $\left(7.0749^{\circ} \mathrm{E}, 54.9998^{\circ} \mathrm{N}, 02: 05 \mathrm{UTC}\right)$ and ends at $\left(1.7726^{\circ} \mathrm{E}\right.$, $\left.42.001^{\circ} \mathrm{N}, 02: 09 \mathrm{UTC}\right)$.

CALIOP (14 to 43\%). Ansmann et al. [2011] retrieved a mean PDR of $36 \pm 2 \%$ at the same wavelength. Our values are more spread due to the heterogeneity of the ash plume. Gasteiger et al. [2011] give a PDR of $35.5 \% \pm 4.4 \%$ corresponding to the upper part of our assessment. Note that the lower limits of the PDR retrieved from GBL and CALIOP are comparable to the lidar linear depolarization ratios of $10-15 \%$ measured in a fresh tropospheric volcanic plume at $0.694 \mu \mathrm{m}$ wavelength by Sassen et al. [2007]. This last value is close to the PDR because the molecular scattering is not dominant at this wavelength.

\subsection{Coherence Using Sunphotometer}

[37] The mean ash plume AOT retrieved from GBL measurements is $0.1 \pm 0.06$ at $355 \mathrm{~nm}$. Such a value is in good agreement with that derived from sunphotometer measurements when comparing the atmospheric conditions before and after the ash plume arrival (Figure 6). The presence of the ash plume is highlighted by a sharp decrease of the
Angstrom exponent calculated between 440 and $675 \mathrm{~nm}$ from $\sim 1.7$ (periurban aerosols) to 1.2. This is associated to the presence of a coarse mode due to the ash plume contribution. Note that a calculation performed on the ash plume AOT derived from the sunphotometer measurements before and during the event leads to a small spectral dependency ( $A \sim 0.3$ between 440 and $675 \mathrm{~nm}$ ).

[38] On the other hand, $\mathrm{N}_{2}$-Raman-derived BER could be compared to the one retrieved from the inversion of the elastic lidar signal with a Klett method [Klett, 1985] using constraint from sunphotometer-derived AOT. This method has been previously used and discussed by Chazette [2003] or Raut and Chazette [2007]. The result is given in Figure 7 following a histogram between the 16 and 19 April 2010. The mean BER is $0.021 \pm 0.005 \mathrm{sr}^{-1}(L R=48 \pm$ $11 \mathrm{sr}$ ), very close to that retrieved from $\mathrm{N}_{2}$-Raman lidar, for which the PBL and ash plume BER are similar. The standard deviation of $0.005 \mathrm{sr}^{-1}$ included the statistical error and the natural variability. Hence, the $B E R=0.022 \mathrm{sr}^{-1}$ retrieved in this study has been validated by two independent ways.

\subsection{Relationship Between Aerosol Mass Concentration and Optical Properties}

[39] The relationship between $\alpha_{a}$ and $P M$ has been well established by Raut et al. [2009a, 2009b] and Raut and Chazette [2009] following the equation:

$$
P M=\underbrace{\rho \cdot \frac{4}{3} \pi \cdot \frac{\overline{r^{3}}}{\overline{\sigma_{a}}}}_{1 / \sigma_{a}^{s}} \cdot \alpha_{a}^{E}
$$

where $\overline{r^{3}}$ is the mean cubic radius, calculated from the ASD, $\sigma_{\alpha}$ (resp. $\sigma_{\alpha}^{s}$ ) is the aerosol mean extinction (resp. specific) cross-section at 355 or $532 \mathrm{~nm}$ over the size range, and $\rho$ is the density of particles. Very limited information is available on both the ash ASD and ACRI, questioning the possibility of a reliable assessment.

\subsubsection{Available Aerosol Size Distribution}

[40] Sunphotometer measurements are available over the Paris area and the AERONET website provides ASDs [Dubovik et al., 2000, 2002] before and during the ash event on 16 April, 2011. Figure 8 presents ASDs before the ash arrived in the morning of 16 April, where the main contribution is due to pollution aerosols belonging to a submicron mode. A coarse mode over $1 \mu \mathrm{m}$ is observed [Randriamiarisoa et al., 2006; Chazette et al., 2005b] but does not bring a dominant contribution on the cross-section $(\sim 19 \%)$. The gray area gives the variability of the sunphotometer-derived ASD during the ash event from 16 to 19 April. The first mode is due the local pollution and the coarse mode is enhanced because of the presence of ash. In the following, we only consider the coarse mode, assuming that the ash plume over Paris was affecting that mode. The volume (or mass) modal radius is found in the range 1 to $5 \mu \mathrm{m}$ with a geometric dispersion between 1.9 and 2. Contributions of sulfate aerosols, which may affect the submicron mode, have been neglected because ash contribution was dominant [Ansmann et al., 2011]. Note that the ACRI available on the AERONET web site during the ash event are between 1.51 and 1.54 for the real part and -0.013 to -0.017 for the imaginary part. Such retrieval is obviously highly influenced by the pollution 


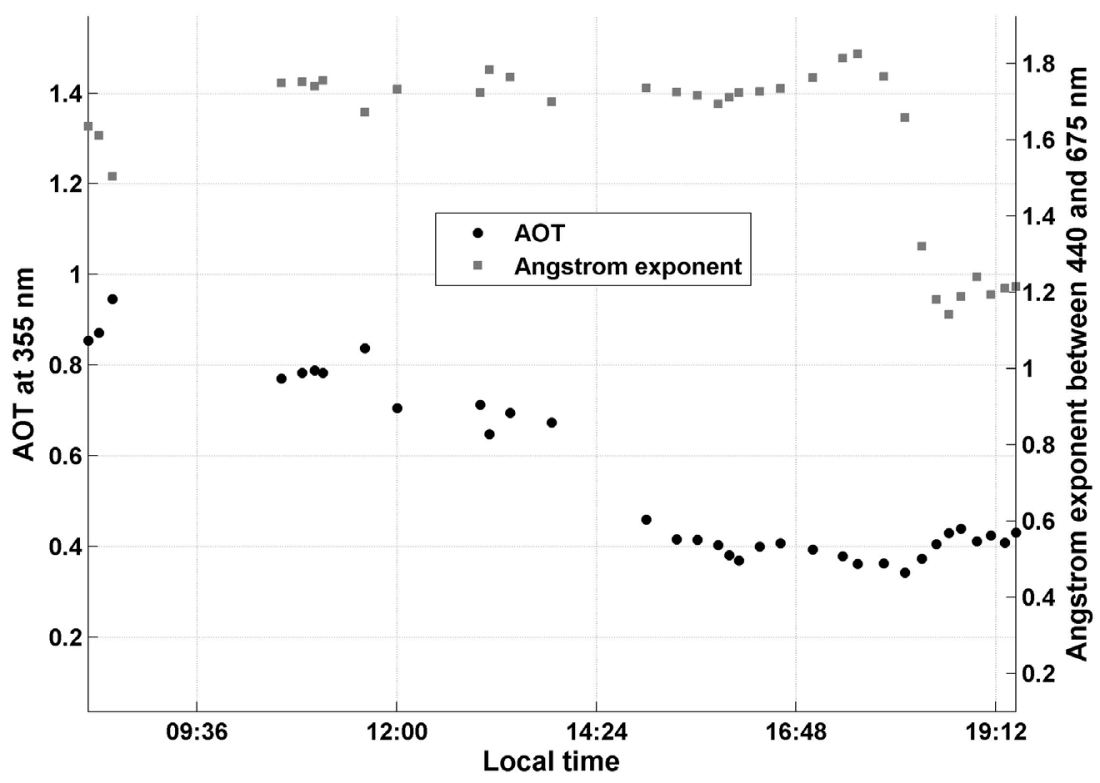

Figure 6. Aerosol optical thickness at $355 \mathrm{~nm}$ and Angstrom exponent between 440 and $675 \mathrm{~nm}$ derived from the Palaiseau/Paris AERONET ground-based station (http://aeronet.gsfc.nasa.gov/) for 16 April 2010.

aerosols trapped within the PBL. Before the ash event, an ACRI of 1.48-i0.015 was retrieved. The choice of the ACRI does not significantly affect the geometrical dispersion but can influence the modal radius.

[41] Schumann et al. [2011] performed airborne measurements over Germany into the ash plume on 19 April 2010. ASD derived from these measurements is also given in Figure 8 with an ACRI of $1.59-0.008$ i. This likely value has been assessed from airborne chemical sampling following the same methodology presented by Raut and Chazette [2007]. Schumann et al. [2011] have also considered less absorbent particles $(1.59-0 \mathrm{i}$ and $1.59-0.004 \mathrm{i})$ but such values lead to very small effective cross-sections, less than $0.1 \mathrm{~m}^{2} \mathrm{~g}^{-1}$. Schumann et al. [2011] have also selected a $\rho$ value of $2.6 \mathrm{~g} \mathrm{~cm}^{-3}$ estimated from chemical analysis of airborne impactor samples, which is in the range of the expected density of ash plume that varies from 0.7 to $3.2 \mathrm{~g} \mathrm{~cm}^{-3}$ (http://volcanoes.usgs.gov/ash/properties.html\# density). We have assumed the same value. The number size distribution retrieved from Schumann et al. [2011] is not in agreement with BER derived from GBL or CALIOP, shifting the mode toward the smaller radii. Indeed, $B E R=0.035 \mathrm{sr}^{-1}$ for particle radius $>0.18 \mu \mathrm{m}$ with $A C R I=1.53-0.008 \mathrm{i}$ and more for the ACRI real part of 1.59. Hereafter the modal radius was investigated from a sensitivity study based on lidar-derived BER.

\subsubsection{Solutions for the Specific Cross-Section $\boldsymbol{\sigma}_{\alpha}^{\boldsymbol{s}}$}

[42] Assuming absorbent spherical particles, $\sigma_{\alpha}^{s}$ has been assessed using a sensitivity study relying on BER values for a monomodal lognormal ASD as input of a Mie code [Raut and Chazette, 2008]. ASD has been defined from the corresponding mass modal radius $r_{m}$ and geometrical dispersion $\sigma_{1}$. Two likely ACRI have been assumed: 1.590.008i [Schumann et al., 2011] and 1.53-0.008i (for dust [Raut and Chazette, 2008]). The latter has been used because its real part is very close to ACRI retrieved from sunphotometer measurements. The imaginary part is lower and most likely closer to the dust contribution. As shown in Figure 9, several solutions exist when considering the uncertainty on BER at the wavelength of $355 \mathrm{~nm}$ and with an ACRI of 1.59-0.008i. However, for a likely range of $\sigma_{l} \in[1.9,2] r_{m}$ is found in the interval $[3.4,5.2] \mu \mathrm{m}$. Considering the second ACRI, the same range of $\sigma_{l}$ leads to $r_{m} \in[2.2,3.4] \mu \mathrm{m}$ and it is also a possible solution and is consistent with the sunphotometer-derived ASD. Then, $\sigma_{\alpha}^{s}$ has been calculated using the same procedure (Figure 9). The two previous possibilities lead to $\sigma_{\alpha}^{s}=0.19 \pm$

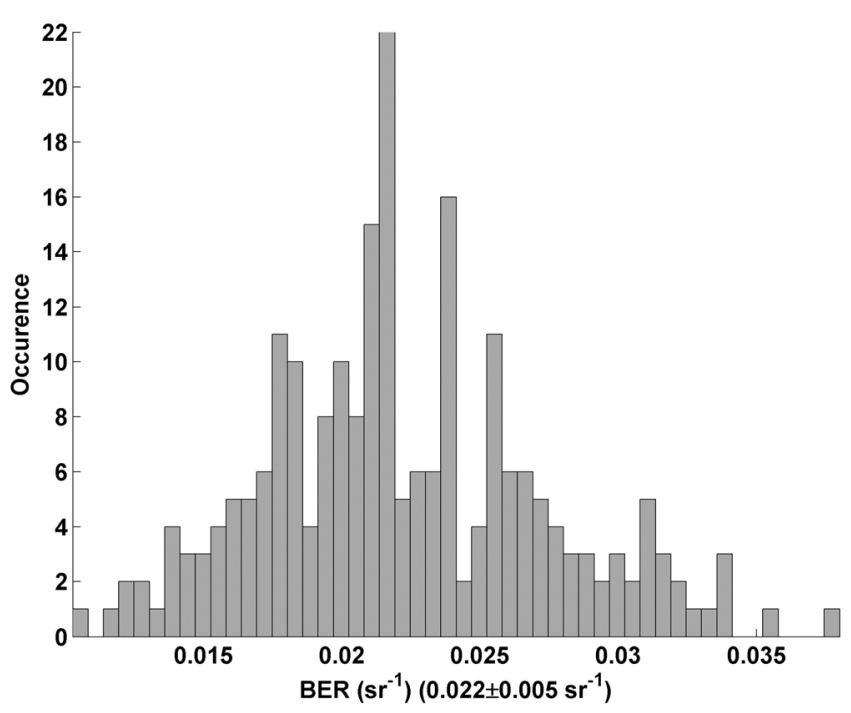

Figure 7. BER retrieved from the synergy between groundbased lidar and sunphotometer from the 16 to 20 April 2010. The mean value is $0.022 \mathrm{sr}^{-1}$ with a standard deviation of $0.005 \mathrm{sr}^{-1}$. 


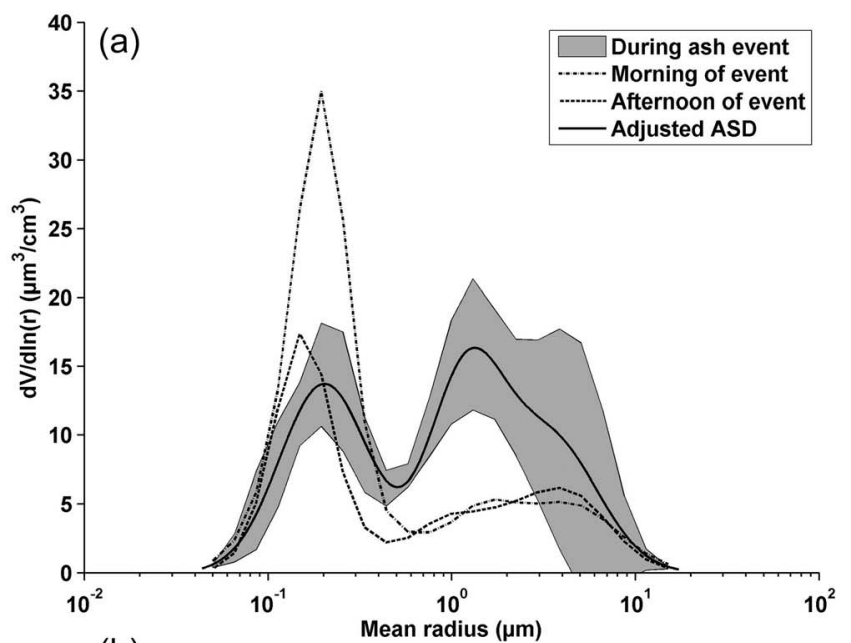

(b)

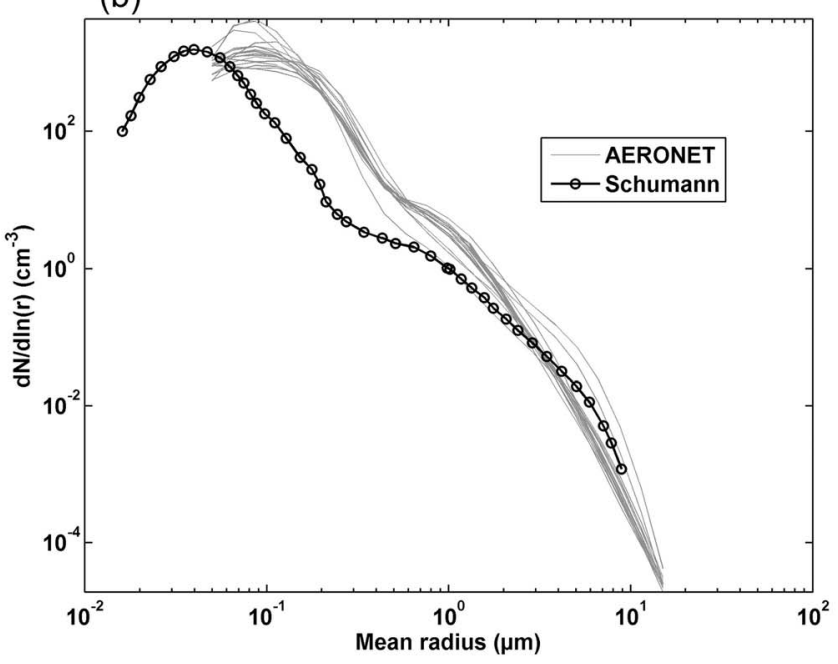

Figure 8. (a) The volume ASDs retrieved from the sunphotometer of Palaiseau (AERONET) during the ash plume event (gray area), the morning and afternoon of the event (before the arrival of ash plume), and the adjusted ASD on the mean sunphotometer-derived ASD during the event. (b) The comparison between the number ASDs retrieved by Schumann et al. [2010] from airborne measurements performed inside the ash plume over Germany the 19 April 2010 (complex refractive index of 1.59-0.008i) and the AERONET retrieval over the station of Palaiseau.

$0.03 \mathrm{~m}^{2} \mathrm{~g}^{-1}$ and $0.29 \pm 0.04 \mathrm{~m}^{2} \mathrm{~g}^{-1}$, respectively. These values provide a likely range of solutions for $\sigma_{\alpha}^{s}$ and have been used to convert AEC to PM.

[43] The best fit on mean sunphotometer-derived ASD during the ash plume event is also given on Figure 8a. It is well defined by 3 modes within $\sim 10 \%:\left(r_{m}=0.202 \mu \mathrm{m}\right.$, $\left.\sigma_{l}=1.75, x=0.386\right),\left(r_{m}=1.20 \mu \mathrm{m}, \sigma_{l}=1.60, x=0.335\right)$ and $\left(r_{m}=3.5 \mu \mathrm{m}, \sigma_{l}=1.80, x=0.279\right)$, where $x$ is the occupation rate. Assuming the two last modes are representative of ash, it is then possible to extract the solution in terms of ACRI as shown Figure 9c. So far the last two modes have been gathered in finding the range of likely modal radius. According to this approach, ACRI given by Schumann et al. [2011] cannot be a solution with an imaginary part of $-0.008 \mathrm{i}$; this value should be at least increased (a)
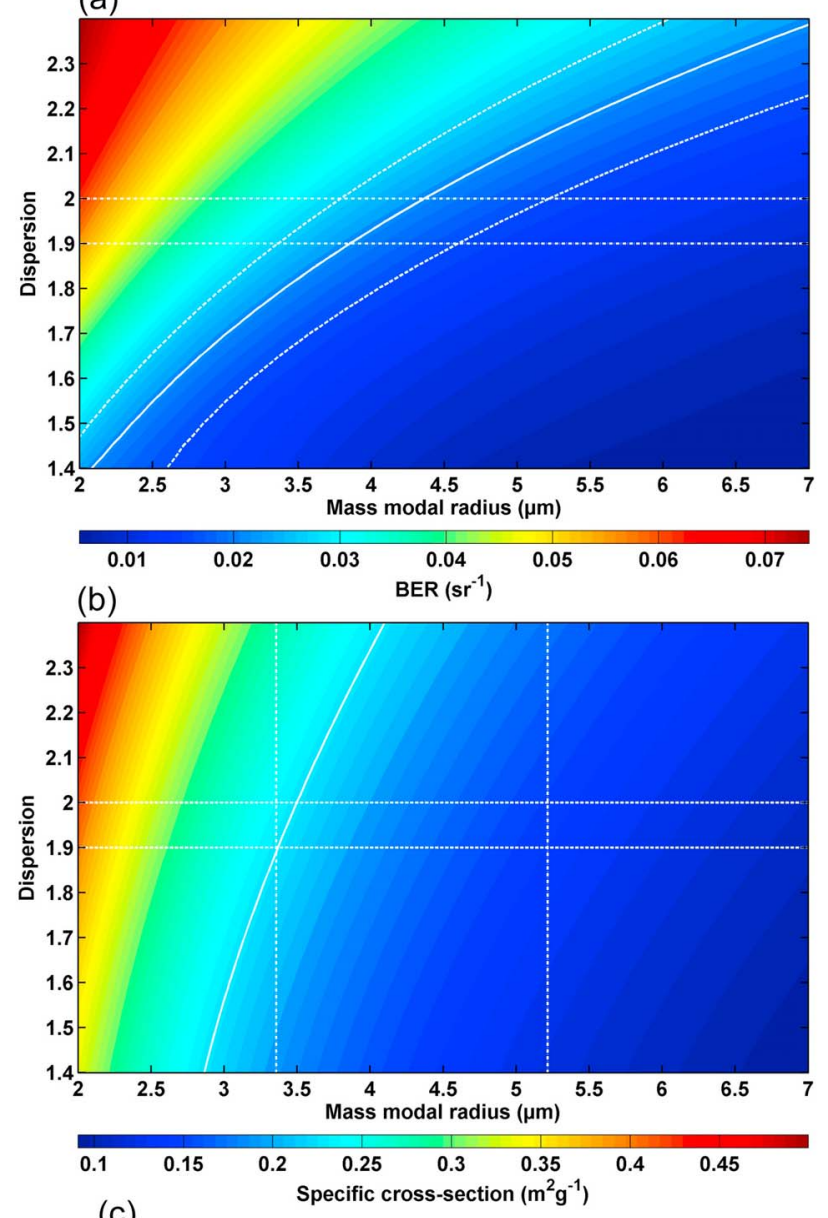

(c)

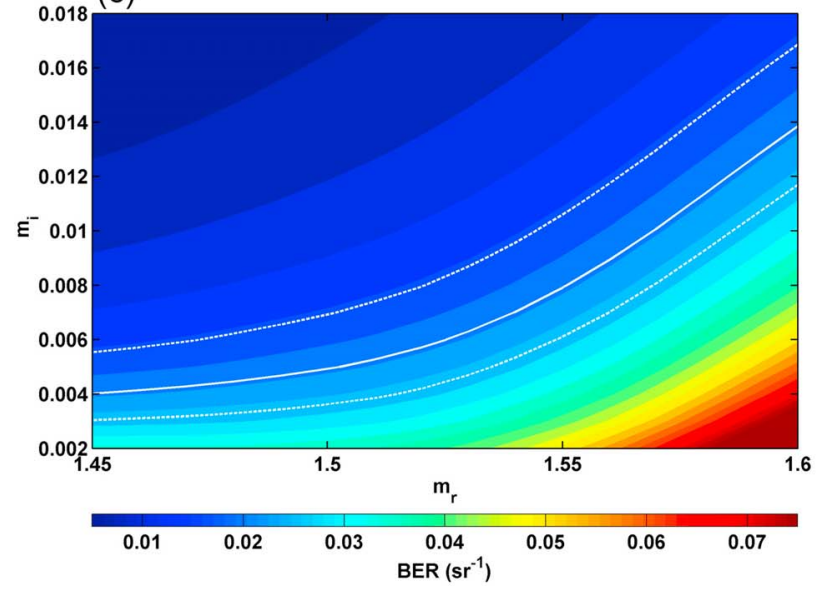

Figure 9. (a) BER against both the geometrical dispersion and the mass modal radius $r_{m}$ for monomodal lognormal distributions. The value corresponding to $B E R=0.022 \mathrm{sr}^{-1}$ is given by a white solid line. (b) The specific cross-section $\sigma_{\alpha}^{s}$ against both the geometrical dispersion and the mass modal radius $r_{m}$. The value corresponding to $\sigma_{\alpha}^{s}=0.23 \mathrm{~m}^{2} \mathrm{~g}^{-1}$ is given by a white solid line. (c) BER against both the real and imaginary parts of ACRI for the coarse aerosol modes $\left(r_{m}=1.15 \mu \mathrm{m}\right.$ and $\sigma_{l}=1.60$, and $r_{m}=3.50 \mu \mathrm{m}$ and $\sigma_{l}=$ 1.80). The value corresponding to $B E R=0.022 \mathrm{sr}^{-1}$ is given by a white solid line. The dotted lines surround the likely solution considering $\sigma_{l} \in[1.9,2]$ and $B E R \in[0.017$, $0.027] \mathrm{sr}^{-1}$. 

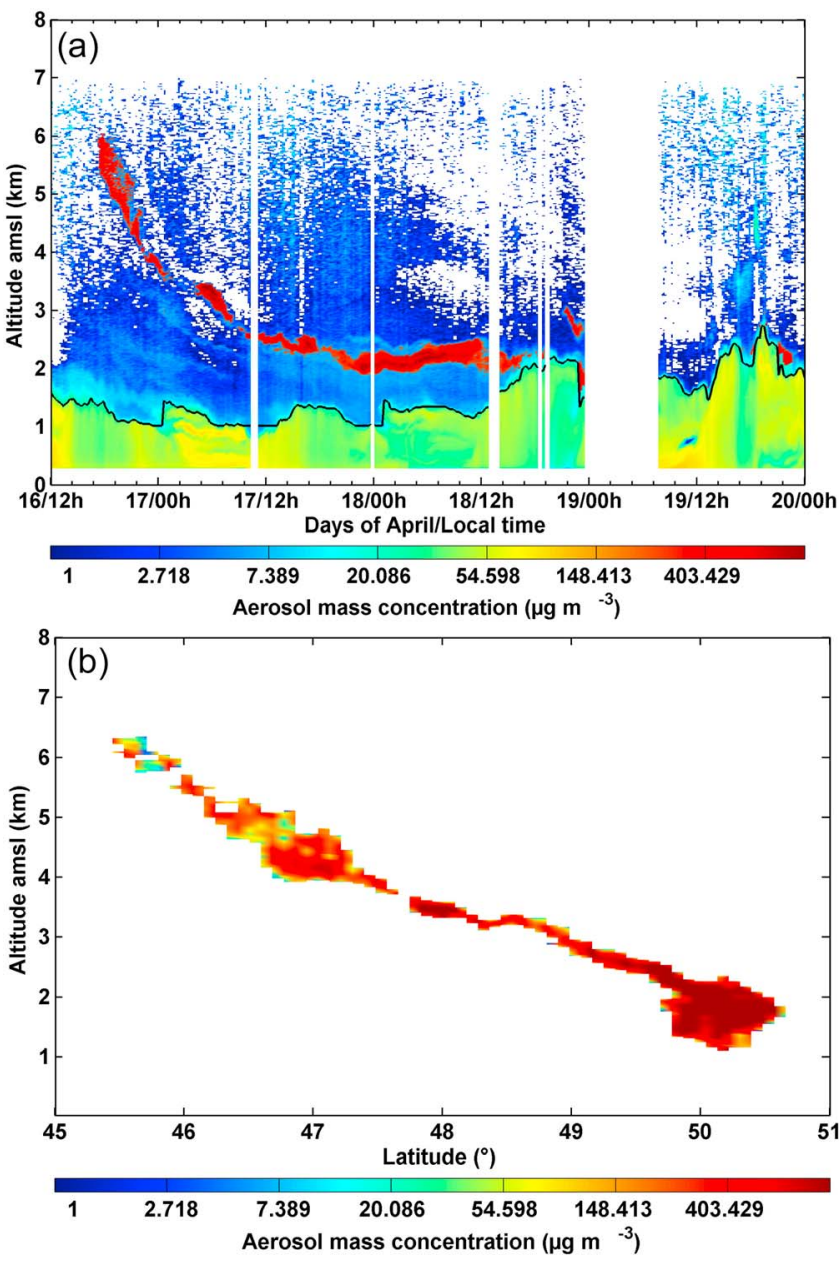

Figure 10. (a) The temporal evolution of the aerosol mass concentration (PM) derived from GBL at 355.The PBL top height is also indicated in the top figure by the black line. (b) The spatial evolution of PM derived from CALIOP at $532 \mathrm{~nm}$ on 17 April. The CALIPSO/CALIOP transect begins at $\left(7.0749^{\circ} \mathrm{E}, 54.9998^{\circ} \mathrm{N}, 02: 05 \mathrm{UTC}\right)$ and ends at $\left(1.7726^{\circ} \mathrm{E}, 42.001^{\circ} \mathrm{N}, 02: 09 \mathrm{UTC}\right)$.

by $50 \%$. ACRI given by Raut and Chazette [2008] turns out to be a robust solution among all others highlighted in Figure 9c with the dotted curves. The specific cross section is poorly sensitive to the choice of ACRI and stays close to $0.23 \mathrm{~m}^{2} \mathrm{~g}^{-1}$ because the aerosol size is large in comparison to the wavelength of $355 \mathrm{~nm}$. Such a value of $\sigma_{\alpha}^{s}$ belongs to the previous range of solution $[0.19 \pm 0.03,0.29 \pm 0.04] \mathrm{m}^{2} \mathrm{~g}^{-1}$ (see Figure 9b).

[44] Now, when considering BER and AEC derived from CALIOP at $532 \mathrm{~nm}$, similar ranges of the mass
Table 5. Relative Uncertainties on the Aerosol Mass Concentration (PM) Derived From Lidar Measurements, Assuming All Errors to Be Independent

\begin{tabular}{lc}
\hline \multicolumn{1}{c}{ Uncertainty Origin } & Relative Uncertainty (\%) \\
\hline Monomodal ASD for coarse particles & $\sim 15$ \\
Aerosol aspect ratio (taken to 2) & $\sim 7$ \\
AEC for GBL & $\sim 20$ \\
AEC for CALIOP & $\sim 30$ \\
Specific cross-section & $\sim 65$ \\
Total uncertainty assuming all errors & $\sim 75$ \\
$\quad$ to be independent & \\
\hline
\end{tabular}

${ }^{\mathrm{a}}$ Schuman et al. [2011].

modal radius are obtained for the two ACRI: [4.7, 6.9] $\mu \mathrm{m}$ and $[3.0,4.5] \mu \mathrm{m}$, respectively. $\sigma_{\alpha}^{s}$ is lower: $0.13 \pm 0.02$ and $0.21 \pm 0.03 \mathrm{~m}^{2} \mathrm{~g}^{-1}$, respectively.

\subsubsection{Lidar-Derived PM}

[45] The GBL- and CALIOP-derived aerosol mass concentrations are given in Figure 10 and will be used hereafter to compare with the modeling approach. GBL-derived PM is shared in two contributions since the PBL traps aerosols emitted from the surface and the ash plume. The PBL top height has been retrieved using the wavelet approach as defined by Brooks [2003] and used by Baars et al. [2008]. The specific cross section is different in these two layers and has been set to $5.9 \mathrm{~m}^{2} \mathrm{~g}^{-1}$ for PBL over Paris area [Raut and Chazette, 2009]. Using an ACRI of 1.59-0.008i, the mean $\mathrm{PM}$ within the ash plume in cloud-free condition $\left(\alpha_{a}^{E} \in\right.$ $[0.02,0.5] \mathrm{km}^{-1}$ ) is $400 \pm 160$ and $720 \pm 670 \mu \mathrm{g} \mathrm{m}^{-3}$ for GBL and CALIOP, respectively. The value is about $40 \%$ lower considering an ACRI of 1.53-0.008i.

\subsubsection{Uncertainty on PM}

[46] The total uncertainty on lidar-derived PM is mainly due to 4 causes: the lidar-derived AEC, ACRI, ASD and the aerosol aspect ratio. Note that the aerosol density $\rho$ is assumed to be a minor error source. Tables 4 and 5 summarize the aerosol microphysical properties and all sources of uncertainty, respectively. The uncertainty on AEC has been assessed to $\sim 0.03(\sim 0.045) \mathrm{km}^{-1}$ for GBL (CALIOP). Within the ash plume, such an uncertainty leads to a relative error of $\sim 20 \%$ (30\%) on lidar-derived PM. Both ACRI and ASD directly influence the specific cross-section $\sigma_{\alpha}^{s}$. Only an absorbent aerosol can present a likely value of $\sigma_{\alpha}^{s}$ but different real parts of the ACRI are possible. Two reasonable ACRI have been considered for this study, the first one being given from airborne measurements and the second one previously considered for dust aerosols. This defines a confidence interval for $\sigma_{\alpha}^{s}$. It is associated to a relative error of $\sim 65 \%$ on lidar-derived PM. ASD is derived from AERONET sunphotometer measurements. Using the monomodal lognormal distribution with a geometrical dispersion

Table 4. Aerosol Microphysical Properties Used to Assess the Uncertainty on the Aerosol Mass Concentration (PM) ${ }^{\mathrm{a}}$

\begin{tabular}{|c|c|c|c|c|}
\hline & \multicolumn{2}{|c|}{ GBL } & \multicolumn{2}{|c|}{ CALIOP } \\
\hline & Schuman et al. [2010] & Raut and Chazette [2008] & Schuman et al. [2010] & Raut and Chazette [2008] \\
\hline ACRI & $1.59-0.008 \mathrm{i}$ & $1.53-0.008 \mathrm{i}$ & $1.59-0.008 \mathrm{i}$ & $1.53-0.008 \mathrm{i}$ \\
\hline Range of mass modal radius $r_{m}(\mu \mathrm{m})$ & {$[3.5,5.2]$} & {$[2.1,3.2]$} & {$[4.7,6.9]$} & {$[2.8,4.3]$} \\
\hline Specific cross-section $\sigma_{a}^{s}\left(\mathrm{~m}^{2} / \mathrm{g}\right)$ & $0.19 \pm 0.03$ & $0.29 \pm 0.04$ & $0.13 \pm 0.02$ & $0.21 \pm 0.03$ \\
\hline
\end{tabular}

${ }^{a}$ Range of geometrical dispersion $\sigma_{1}$ : [1.9, 2]. Aerosol density is assumed to be constant with $\rho=2.6 \mathrm{~g} / \mathrm{cm}^{3}$ [Schuman et al., 2011]. 

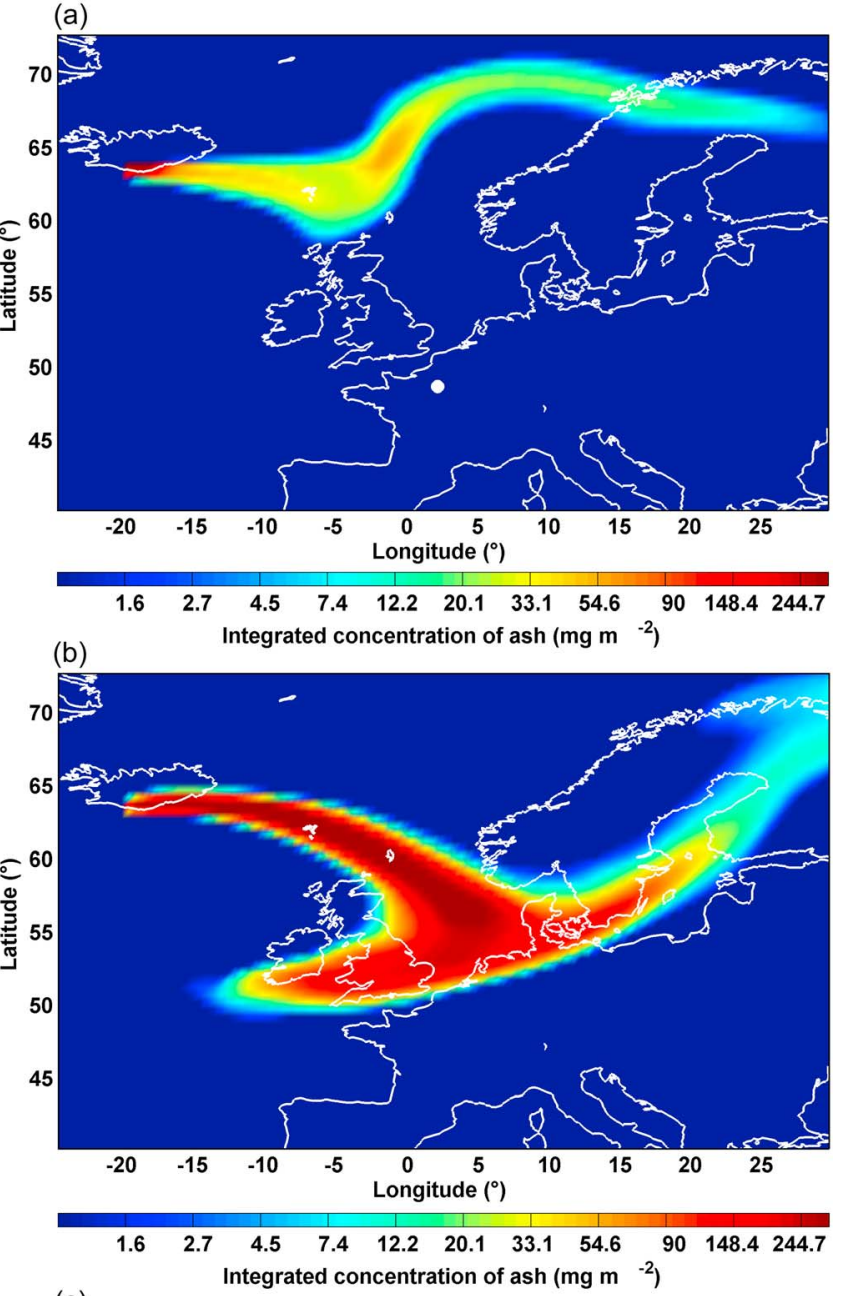

(c)

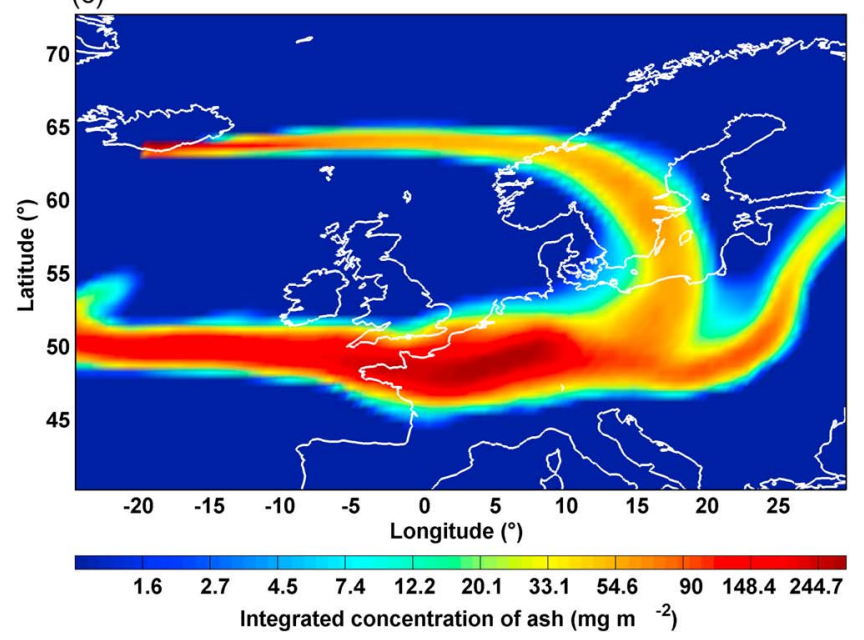

Figure 11. Snapshots of the columns of the ash plume across Europe for (a) 15, (b) 16 and (c) 17 April 2010. The concentrations scale is logarithmic. The Saclay site is indicated with a white point (Figure 11a).

between 1.9 and 2 taken from the sunphotometer-derived coarse mode, the relative error on PM is $\sim 15 \%$. The influence of an aerosol aspect ratio of 2, given by the work of Schumann et al. [2011], has also been studied. This sensitivity test has been carried out using the T-Matrix algorithm [Mishchenko and Travis, 1998] at the wavelength of $532 \mathrm{~nm}$. Indeed the convergence could not been obtained at $355 \mathrm{~nm}$, due to a too large aerosol size parameter. At
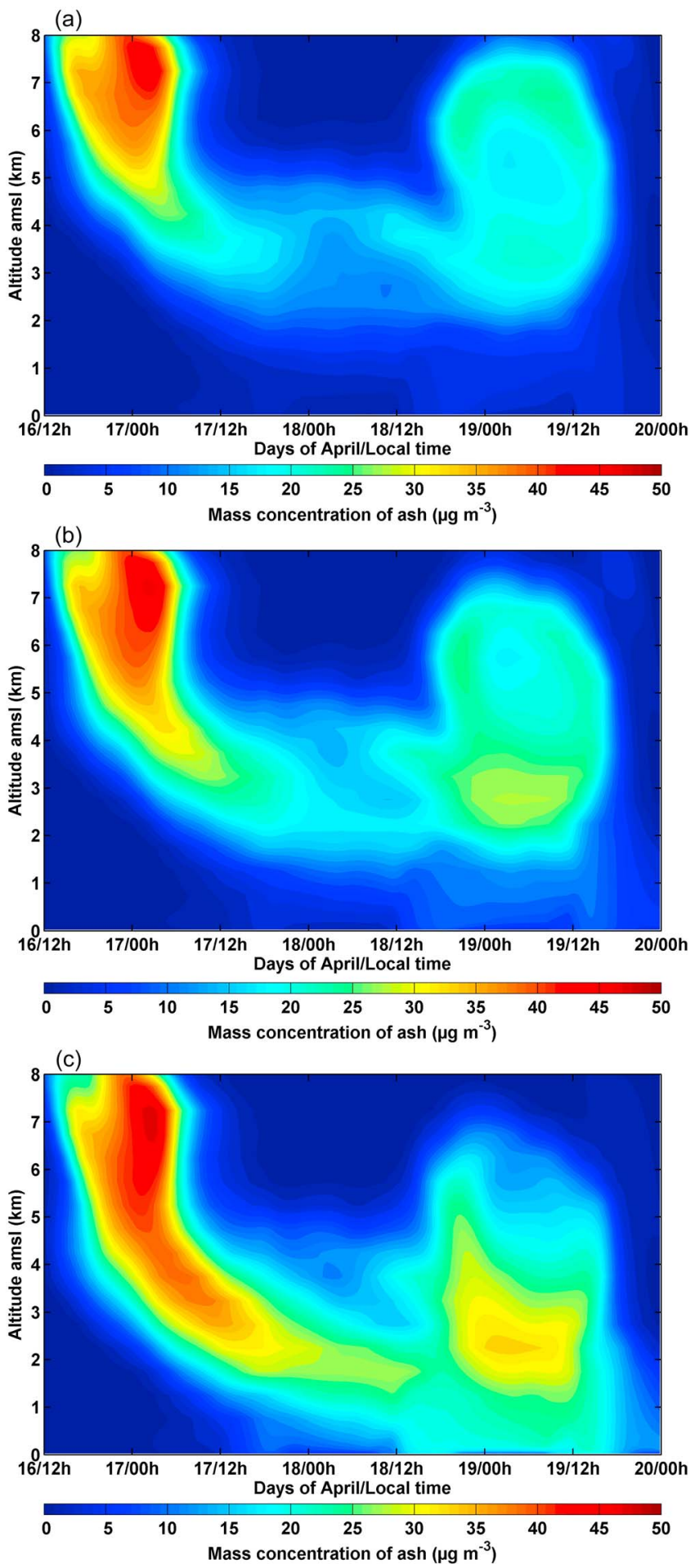

Figure 12. Temporal evolution of the aerosol mass concentration assessed with Polair3D. Different monodisperse distributions are considered for aerosol physical radii of (a) 3 , (b) 5, and (c) $7 \mu \mathrm{m}$. 

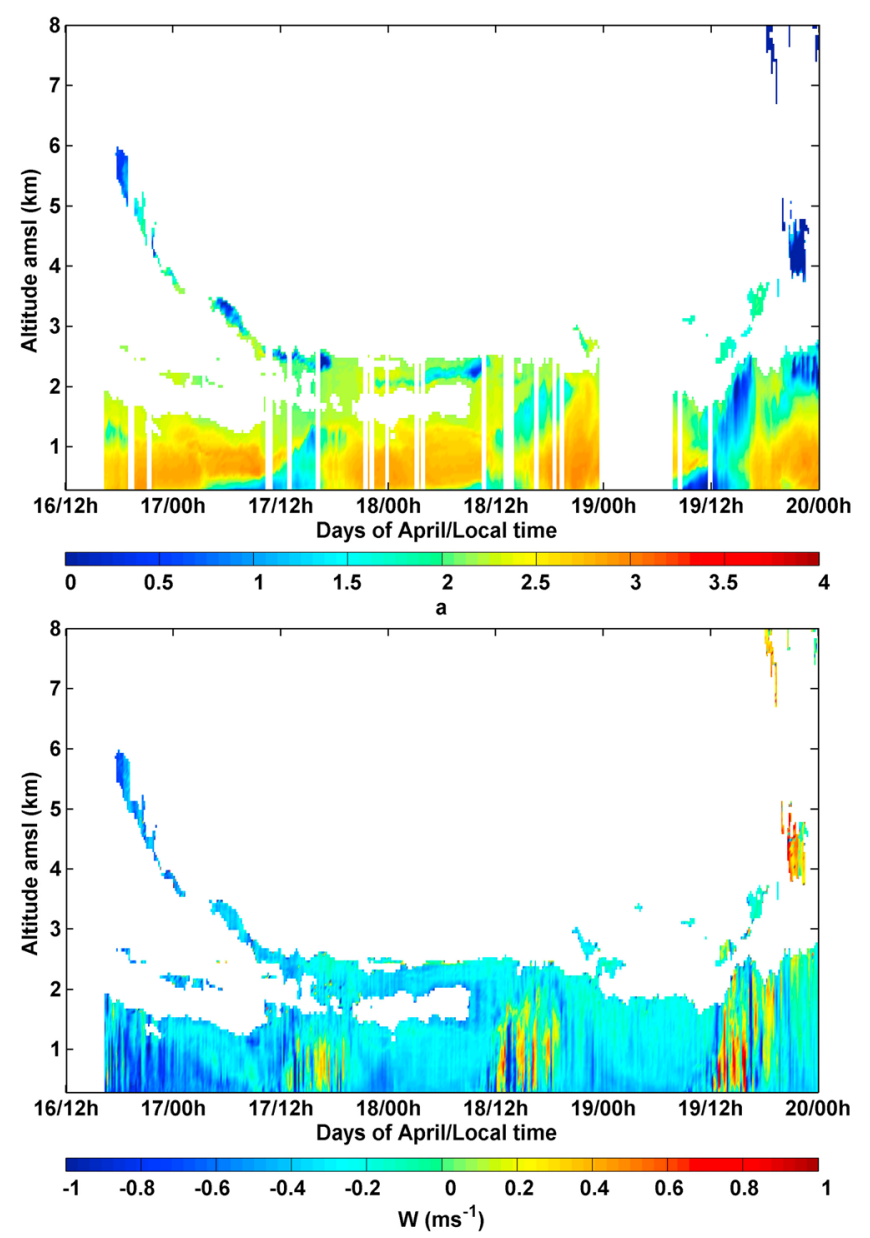

Figure 13. (a) The temporal evolution of the pseudo Angstrom exponent $(a)$ derived from the elastic channel of the $\mathrm{N}_{2}$-Raman (355 $\mathrm{nm}$ ) and the WINDCUBE200 (1543 nm) systems. (b) The vertical wind (W) derived from the windlidar (WINDCUBE200).

$532 \mathrm{~nm}$, the discrepancy on $\sigma_{\alpha}^{s}$ between spherical and nonspherical particles was found to be $\sim 7 \%$.

[47] Assuming all errors independent would lead to a total relative error on lidar-derived PM close to $75 \%$. This is actually not the case since the assessment of $r_{m}$ is also a function of ACRI, thus overestimating the relative error on PM.

\section{Results From the Modeling Approach}

\subsection{Emission Scenario and Plume Extent}

[48] Several scenarii of emissions were selected to compare the plume simulations at Saclay and along the CALIPSO track on 17 April 2010, with the GBL profiles. We have identified from these numerical experiments the most sensitive parameters.

[49] First, the source term profile both in time and height is crucial. Because the plume rise could reach more than $10000 \mathrm{~m}$ above the caldera, the ashes were dispersed by winds of several orders of magnitude including high altitude jet streams. Therefore the precise injection height or range of altitudes of the ashes tracer in the model is determining. The schedule of the release is also essential. In our simulation, the daily estimation of released mass was uniformly distributed over $24 \mathrm{~h}$, whereas the volcano only ejected mass intermittently. Besides, because of the complex atmospheric transport, the relationship between the emission and the lidar profile is non-trivial. For instance, the profile in Saclay is not related to the emission on 14 April because of the low pressure system over North Scandinavia that first dispersed the ash toward Scandinavia. On the contrary, it is quite sensitive to what was emitted on 15 April and a finer temporal distribution for the emission on 15 April is desirable over our current uniform distribution.

[50] Simulation results are sensitive to the meteorological winds uncertainty but this could not be quantified easily in this study. Furthermore, the local wind speed derived from wind lidar shows a good agreement between simulations and measurements concerning the temporal evolution of the vertical profile of the horizontal wind speed (not shown) over Saclay site. The ash plume advection seems to occur from South-West to North-East with a horizontal velocity $\sim 15 \mathrm{~ms}^{-1}$.

[51] Following the eruption of 14 April 2010, the ash plume is advected east-northeastward (Figure 11a), then transported southeastward (Figure 11b) before spreading in two branches (Figure 11c): one in the southwestern and the other one in the northeastern direction. The Saclay site was under the second branch.

\subsection{Ash Particle Size}

[52] Using a monodisperse distribution for the ash particles, it was found that a physical radius between 3 and $5 \mu \mathrm{m}$ allows a better match with the lidar profiles shape as shown in Figure 12. It is found that the first branch of the ash plume from the night of 16 to 17 April noon barely penetrates the PBL. However, the second branch in the morning of 19 April seems to have penetrated the PBL with a uniform increment of $\mathrm{PM} \sim 30 \mu \mathrm{g} \mathrm{m}^{-3}$ (see section 5.5).

[53] The shape of the simulated profile is strongly impacted by the sedimentation process. Depending on the mode of the ash size distribution, the profile can get closer to the ground $(R>7 \mu \mathrm{m})$ or remains at $6000 \mathrm{~m}(R<3 \mu \mathrm{m})$. However, the descending shape of the ash on the GBL profile is neither a signature of sedimentation or of the emission injection heights, but is more likely due to meteorology: only the position of the ashes in this descending corridor gives away the sedimentation rate. We have checked that the horizontal modulus of the wind over the volcano had a strong shear from $10 \mathrm{~ms}^{-1}$ at the ground to $55 \mathrm{~ms}^{-1}$ at $10 \mathrm{~km}$ height from 14 to 16 April 2010. Besides, this shear can be observed along the plume trajectory from Iceland to Scandinavia. We believe this primarily explains the vertically tilted shape of the plume. The sensitivity to sedimentation is due to the fact that the ash reaching Saclay or present in the CALIOP profiles have been emitted only 2 to 5 days ago. As a consequence, such a short-term simulation is quite dependent on the initial ASD. The size mode of the ash does not only impact the shape of the profile but also the scale of the concentrations, because a mode shifted toward higher sizes would imply stronger deposition and higher loss of mass from the volcano to the locations of GBL observations. 

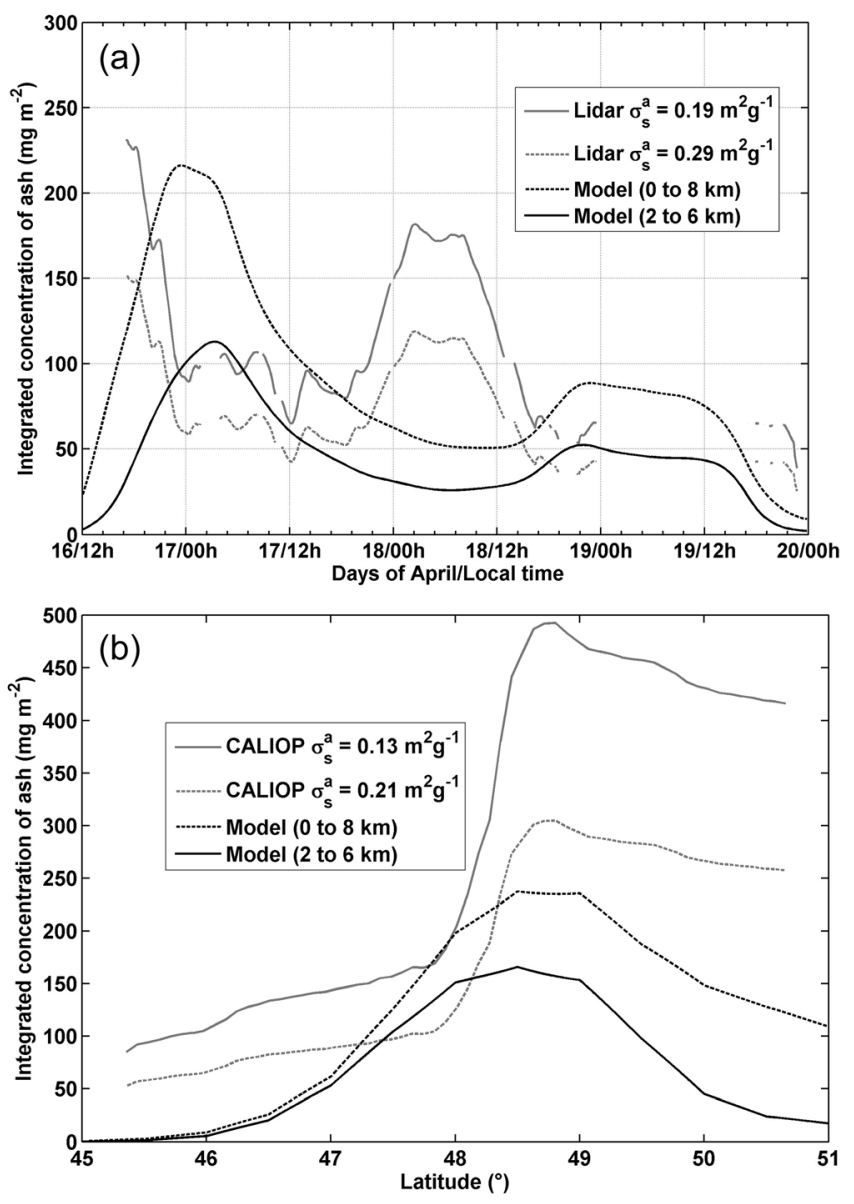

Figure 14. Integrated aerosol mass concentration derived from GBL, CALIOP and Polair3D: (a) comparison between GBL and Polair3D, and (b) comparison between CALIOP and Polair3D for 17 April 2010. The comparisons are for two plausible specific cross-sections $\left(\sigma_{s}^{a}\right)$ and for different vertical integration ( 0 to $8 \mathrm{~km}$ and 2 to $6 \mathrm{~km}$, above the top of PBL).

[54] At Saclay, we can consider, at least over a short period of time (1-2 days) when the meteorological conditions do not change, that the observed particles have the same lifetime. In consequence, the selection of a representative radius (i.e., 3-5 $\mathrm{m}$ ) might be an acceptable approximation for the observed profile. The argument is no longer valid when comparing the simulations with lidar observations given by the CALIPSO platform. On 17 April, the transect begins at $\left(7.0749^{\circ} \mathrm{E} ; 54.9998^{\circ} \mathrm{N}, 02: 05 \mathrm{UTC}\right)$ and ends at $\left(1.7726^{\circ} \mathrm{E} ; 42.001^{\circ} \mathrm{N}, 02: 09\right.$ UTC). Thus, the plume trace intercepted by the transect contains particles of many different lifetimes, and, as a consequence, with a rather broad ASD. To give accurate results for the prominent part of the plume (in the north of the trajectory, at around $50^{\circ} \mathrm{N}$, consequently with a shorter lifetime than the particles observed at Saclay), it was checked that a representative radius was found to be $\sim 7-10 \mu \mathrm{m}$. Yet, at the south of the transect, a more adequate ASD would have its mode at a shorter radius (typically $3-5 \mu \mathrm{m}$ ). It would in principle be preferable to abandon the monodispersed distribution approximation, but precise information about ASD is missing.

[55] As a sensitivity test, we have also simulated a lognormal ASD around the mode $r_{m}=3-5 \mu \mathrm{m}$. The geometric standard deviation of the lognormal distribution was given the reasonable value of 1.3 [Stohl et al., 2011] and 1.9. The results were however quite similar to the monodisperse distribution. Indeed the ash with a size close to $5 \mu \mathrm{m}$ obviously present a similar profile. Ash with a size significantly greater than $9 \mu \mathrm{m}$ are found closer to the ground or deposited but they represent a minor fraction of the mass. Ash with a size significantly lower than $5 \mu \mathrm{m}$ are found higher $(5-7 \mathrm{~km})$ but they represent a minor fraction of the mass too. The net result is a profile which is vertically stretched but similar to the monodisperse case profile with a radius between 3 and $5 \mu \mathrm{m}$.

\subsection{Spectral Dependency Derived From Lidar: Consistency With the Aerosol Size}

[56] Using the GBL measurements from elastic channel of $\mathrm{N}_{2}$-Raman (355 nm) and WINDCUBE200 (1543 nm) systems, a pseudo Angstrom exponent $a$ can be calculated after correction of the molecular extinction at $355 \mathrm{~nm}$ using:

$$
\frac{S_{E} \cdot \int_{z_{G}}^{z} \alpha_{m}^{E}\left(z^{\prime}\right) \cdot d z^{\prime}}{S_{W}}=\left(\frac{355}{1543}\right)^{-a}
$$

where $S_{w}$ is the range corrected wind lidar signal. In fact, the Angstrom exponent is here set to a nearest constant, which is a function of the system constants associated to each lidar. Figure 13 gives the temporal evolution of $a$. The signature of the ash plume is well highlighted by a lower value of $a$ $(\sim 0.5)$ in comparison to those retrieved for aerosols trapped into the PBL (2 to 3 ). Note that smaller values of $a$ correspond to the higher values of $V D R$ (Figure 5) and are likely associated to the presence of a coarse aerosol mode. A coarse mode most likely associated to the ash plume penetration inside the PBL can also been identified as shown by low values of $a$ observed at $\sim 12 \mathrm{~h}$ on 19 April 2010, between the ground level and the PBL top. This result is in agreement with the higher values of both $\mathrm{PM}_{10}$ and sulfur dioxide concentration. Moreover, the smaller values of $a$ appear correlated with important vertical convection processes between 12 and $18 \mathrm{~h}$ local time within the PBL (Figure 13) favoring the intrusion of both ash and dust particles from surface within the PBL. The surface was dry with no precipitation for several days. Note that the decrease in the molecular backscattering against the altitude does not significantly affect the value of $a$ within the PBL. The upper layer, where the ash plume is present, is more influenced by the molecular contribution.

\subsection{Aerosol Mass Concentrations}

[57] The Polair3D-derived integrated aerosol mass concentration (IPM) is compared to both GBL and CALIOPderived IPM in Figure 14. The model's IPM and observation-derived IPMs have a similar order of magnitude for both comparisons. GBL (resp. CALIOP) data have been smoothed to reach a temporal (resp. spatial) resolution of $1 \mathrm{~h}$ (resp. $50 \mathrm{~km}$ ) comparable to that of the model. One should keep in mind that simulations from Eulerian models are 

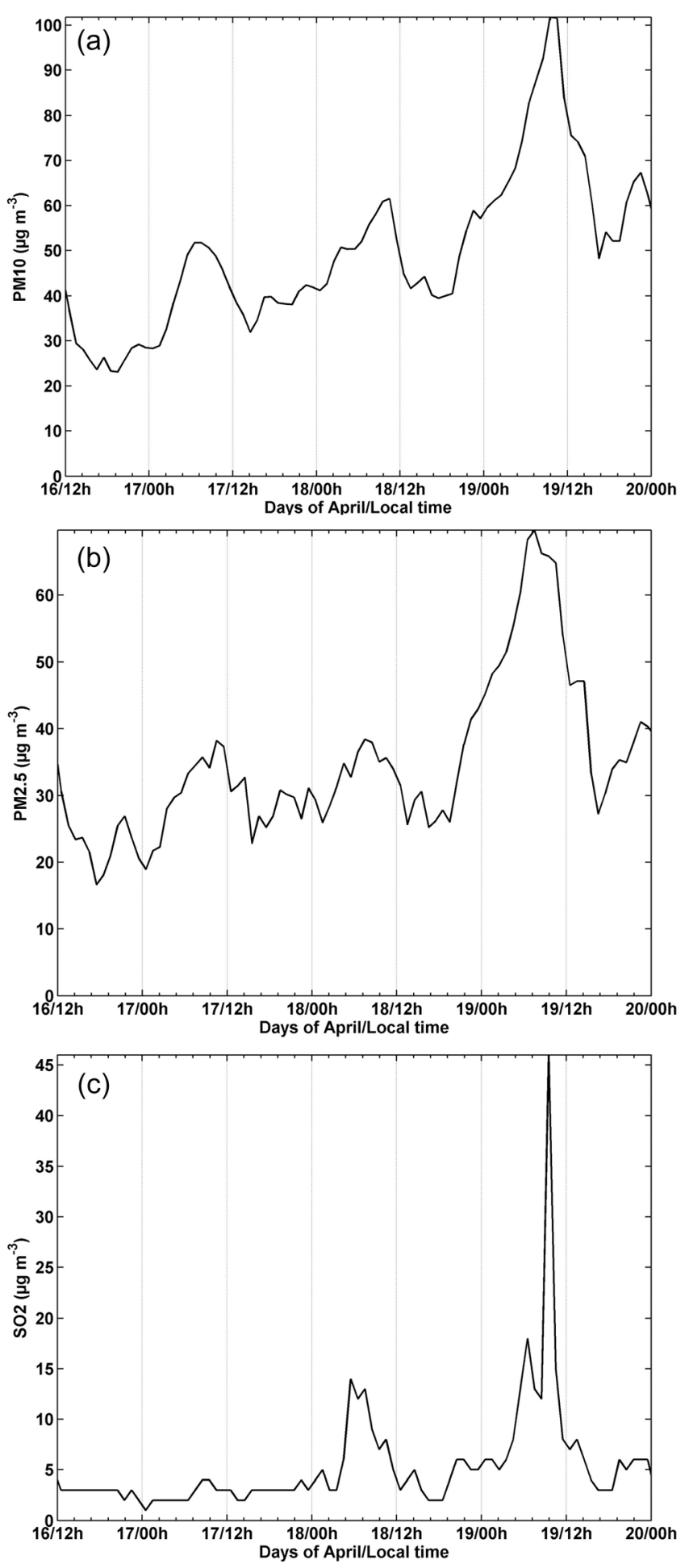

Figure 15. Ground-based measurements performed at the AIRPARIF station of Vitry (South of Paris, http://www.airparif.asso.fr/): (a) $\mathrm{PM}_{10}$, (b) $\mathrm{PM}_{2.5}$ and (c) $\mathrm{SO}_{2}$.

impacted by the representativeness issue. Simulation outputs are coarse-grained (low-pass filtered) views of the actual concentrations reported by lidar measurements. PM retrieved from Polair3D is more spread $(3 \mathrm{~km})$ compared to GBL $(\sim 0.5 \mathrm{~km})$ due to numerical dispersion and thus the PM maximum value could be significantly underestimated
( $\sim 400 \mu \mathrm{g} / \mathrm{m}^{3}$ in the center of the ash plume), even though the integrated mass could be compared. Moreover, the peaks of the plume forecast by simulation should be lower than those inferred from lidar measurements. The vertical integration acts as a partial low-pass filter on the observationderived IPM allowing them to be more easily compared to the model, which explains a better quantitative match between the lidar observations and the model. However, a significant time-shift of about 6 to $9 \mathrm{~h}$ can be noted for the maximum of the first and main peak when comparing with the GBL. Such a shift is not unusual after 48 to $72 \mathrm{~h}$ of dispersion simulation. It is caused by the errors in the meteorological fields that accumulate in the tracer dispersion as well as the excessive diffusion of Eulerian simulations [Krysta and Bocquet, 2007]. No such shift is observed when comparing with CALIOP-derived PM. In this comparison between lidar measurements and modeling results, the ash reaching the PBL are not taken into account in the aerosol mass concentration retrieved from lidar measurements because their identification appears very difficult.

\subsection{Link With Ground-Based Measurements}

[58] VDR retrieved from GBL measurements (Figure 5) shows a possible penetration of the ash plume into the PBL during the night of 18-19 April 2010. This penetration is also predicted by the model (Figure 12). A significant increase of $\mathrm{PM}_{10}$ concentration from $\sim 60$ to $\sim 100 \mu \mathrm{g} \mathrm{m}^{-3}$ is observed from the measurements of AIRPARIF (http:// www.airparif.asso.fr/) ground-based station of Vitry-surSeine (South of Paris) during the morning of 19 April 2010 (Figure 15a). Such a value is in agreement with that derived for ash aerosols from modeling $\left(35 \mu \mathrm{g} / \mathrm{m}^{3}\right)$. A positive trend could also be observed in this figure. The peak is associated to a sharp enhancement of $\mathrm{PM}_{2.5}$ values from $\sim 30$ to $\sim 70 \mu \mathrm{g} \mathrm{m}^{-3}$ (Figure 15b). The proportion of coarse particles is slightly larger than under background conditions. The sulfur dioxide concentration $\left(\mathrm{SO}_{2}\right)$ increases from the background value of $\sim 3$ to $45 \mu \mathrm{g} \mathrm{m}^{-3}$ into the peak (Figure 15c). This may be the signature of ash reaching the ground level.

\section{Conclusion}

[59] The advantage of a tight coupling between transport modeling of the ash plume from the Eyjafjallajökull volcano eruption and the well resolved vertical lidar measurements has been demonstrated here. The plume shape over Saclay (South of Paris) between the 16 and 20 April 2010 helped to define a size range for ash particles between 3 and $5 \mu \mathrm{m}$ in order to compute aerosol mass concentrations of the volcanic plume. This size range appears to be in agreement with a sensitivity study performed using the synergy between $\mathrm{N}_{2}$ Raman lidar or CALIOP (AEC) and sunphotometer (ASD). Complementary measurements were required to determine the aerosol mass concentration from AEC as ACRI and ASD. The ACRI values derived by Schumann et al. [2011] (1.59 -0.008i) and by Raut and Chazette [2009] for dust aerosols $(1.53-0.008 \mathrm{i})$ have been both used to allow a sensitivity study. Between 16 and 20 April 2010, the ash plume was associated with a mean aerosol optical thickness of $\sim 0.08 \pm 0.06$ and $\sim 0.055 \pm 0.053$ for $\mathrm{N}_{2}$-Raman $(355 \mathrm{~nm})$ and CALIOP $(532 \mathrm{~nm})$, respectively. Such values are associated with PM mean values of $\sim 400 \pm 160$ and 
$\sim 720 \pm 670 \mu \mathrm{g} \mathrm{m}^{-3}$, respectively, within the ash plume, which is lower than $0.5 \mathrm{~km}$ width. The relative uncertainty on PM has been assessed to be $\sim 75 \%$. Although PM was underestimated from modeling due to a smoothing effect, the integrated mass was found within the same order of magnitude (between 50 and $250 \mathrm{mg} \mathrm{m}^{-2}$ ).

[60] Acknowledgments. This work was supported by the Centre National d'Etudes Spatiales (CNES) and the Commissariat à l'Energie Atomique (CEA).

\section{References}

Anselmo, T., et al. (2005), Cloud-Aerosol LIDAR Infrared Pathfinder Satellite Observations Data Management System: Data Products Catalog, Rep. PC-SCI-503, 114 pp., NASA Langley Res. Ctr., Hampton, Va. [Available at http://www-calipso.larc.nasa.gov/resources/project_ documentation.php]

Ansmann, A., et al. (2010), The 16 April 2010 major volcanic ash plume over central Europe: EARLINET lidar and AERONET photometer observations at Leipzig and Munich, Germany, Geophys. Res. Lett., 37, L13810, doi:10.1029/2010GL043809.

Ansmann, A., et al. (2011), Ash and fine-mode particle mass profiles from EARLINET-AERONET observations over central Europe after the eruption of the Eyjafjallajokull volcano in 2010, J. Geophys. Res., 116, D00U02, doi:10.1029/2010JD015567.

Baars, H., A. Ansmann, R. Engelmann, and D. Althausen (2008), Continuous monitoring of the boundary-layer top with lidar, Atmos. Chem. Phys. 8, 7281-7296, doi:10.5194/acp-8-7281-2008.

Berthier, S., P. Chazette, P. Couvert, J. Pelon, F. Dulac, F. Thieuleux, C. Moulin, and T. Pain (2006), Desert dust aerosol columnar properties over ocean and continental Africa from Lidar in-Space Technology Experiment (LITE) and Meteosat synergy, J. Geophys. Res., 111, D21202, doi:10.1029/2005JD006999.

Brooks, I. (2003), Finding boundary layer top: Application of a wavelet covariance transform to lidar backscatter profiles, J. Atmos. Oceanic Technol., 20, 1092-1105, doi:10.1175/1520-0426(2003)020<1092: FBLTAO $>2.0 . \mathrm{CO} ; 2$.

Casadevall, T. J. (1994), The 1989-1990 eruption of Redoubt Volcano, Alaska: Impacts on aircraft operations, J. Volcanol. Geotherm. Res., 62, 301-316, doi:10.1016/0377-0273(94)90038-8.

Chazette, P. (2003), The monsoon aerosol extinction properties at Goa during INDOEX as measured with lidar, J. Geophys. Res., 108(D6), 4187, doi:10.1029/2002JD002074

Chazette, P., C. David, J. Lefrère, S. Godin, J. Pelon, and G. Mégie (1995), Comparative lidar study of the optical, geometrical, and dynamical properties of stratospheric post-volcanic aerosols, following the eruption of El Chichon and Mount Pinatubo, J. Geophys. Res., 100(D11), 23,195-23,207, doi:10.1029/95JD02268.

Chazette, P., P. Couvert, H. Randriamiarisoa, J. Sanak, B. Bonsang, P. Moral, S. Berthier, S. Salanave, and F. Toussaint (2005a), Three dimensional survey of pollution during winter in French Alps valleys, Atmos. Environ., 39, 1035-1047, doi:10.1016/j.atmosenv.2004.10.014.

Chazette, P., H. Randriamiarisoa, J. Sanak, P. Couvert, and C. Flamant (2005b), Optical properties of urban aerosol from airborne and groundbased in situ measurements performed during the ESQUIF program, J. Geophys. Res., 110, D02206, doi:10.1029/2004JD004810.

Chazette, P., J.-C. Raut, F. Dulac, S. Berthier, S.-W. Kim, P. Royer, J. Sanak, S. Loaëc, and H. Grigaut-Desbrosses (2010), Simultaneous observations of lower tropospheric continental aerosols with a groundbased, an airborne, and the spaceborne CALIOP lidar systems, J. Geophys. Res., 115, D00H31, doi:10.1029/2009JD012341.

Collis, R. T. H., and P. B. Russell (1976), Lidar measurement of particles and gases by elastic backscattering and differential absorption, in Laser Monitoring of the Atmosphere, edited by E. D. Hinkley, pp. 71-152, Springer, New York.

Davoine, X., and M. Bocquet (2007), Inverse modelling-based reconstruction of the Chernobyl source term available for long-range transport, Atmos. Chem. Phys., 7, 1549-1564, doi:10.5194/acp-7-1549-2007.

Dubovik, O., A. Smirnov, B. N. Holben, M. D. King, Y. J. Kaufman, T. F. Eck, and I. Slutsker (2000), Accuracy assessments of aerosol optical properties retrieved from AERONET sun and sky-radiance measurements, J. Geophys. Res., 105, 9791-9806, doi:10.1029/2000JD900040.

Dubovik, O., B. N. Holben, T. F. Eck, A. Smirnov, Y. J. Kaufman, M. D. King, D. Tanre, and I. Slutsker (2002), Variability of absorption and optical properties of key aerosol types observed in worldwide locations, J. Atmos. Sci., 59, 590-608, doi:10.1175/1520-0469(2002)059<0590: VOAAOP $>2.0 . \mathrm{CO} ; 2$.
Flentje, H., H. Claude, T. Elste, S. Gilge, U. Köhler, C. Plass-Dülmer, W. Steinbrecht, W. Thomas, A. Werner, and W. Fricke (2010), The Eyjafjallajökull eruption in April 2010-detection of volcanic plume using in-situ measurements, ozone sondes and lidar-ceilometer profiles, Atmos. Chem. Phys., 10, 10,085-10,092, doi:10.5194/acp-10-10085-2010.

Gasteiger, J., S. Groß, V. Freudenthaler, and M. Wiegner (2011), Volcanic ash from Iceland over Munich: Mass concentration retrieved from ground-based remote sensing measurements, Atmos. Chem. Phys., 11, 2209-2223, doi:10.5194/acp-11-2209-2011.

Gudmundsson, M. T., R. Pedersen, K. Vogfjörd, B. Thorbjarnardóttir, S. Jakobsdóttir, and M. J. Roberts (2010), Eruptions of Eyjafjallajökull Volcano, Iceland, Eos Trans. AGU, 91(21), 190-191, doi:10.1029/ 2010EO210002.

Hamonou, E., P. Chazette, D. Balis, F. Dulac, X. Schneider, E. Galani, G. Ancellet, and A. Papayannis (1999), Characterisation of the vertical structure of Saharan dust export to the Mediterranean basin, J. Geophys. Res., 104, 22,257-22,270, doi:10.1029/1999JD900257.

Holben, B. N., et al. (1998), AERONET-A federated instrument network and data archive for aerosol characterisation, Remote Sens. Environ., 66 , 1-16, doi:10.1016/S0034-4257(98)00031-5.

Hostetler, C. A. Z Liu, J. Reagan, M. Vaughan, D. Winker, M. Osborn, W. H. Hunt, K. A. Powell, and C. Trepte (2005), CALIOP algorithm theoretical basis document-Part 1: Lidar level I ATBD - Calibration and level 1 data products, Rep. PC-SCI-201, 66 pp., NASA Langley Res. Ctr., Hampton, Va. [Available at http://www-calipso.larc.nasa.gov/ resources/project documentation.php.]

Hunt, W. H., D. M. Winker, M. A. Vaughan, K. A. Powell, P. L. Lucker, and C. Weimer (2009), CALIPSO lidar description and performance assessment, J. Atmos. Oceanic Technol., 26, 1214-1228, doi:10.1175/ 2009JTECHA1223.1.

Kim, S. W., S. Berthier, J.-C. Raut, P. Chazette, F. Dulac, and S.-C. Yoon (2008), Validation of aerosol and cloud layer structures from the spaceborne lidar CALIOP using a ground-based lidar in Seoul, Korea, Atmos. Chem. Phys., 8, 3705-3720.

King, L. V. (1923), On the complex anisotropic molecule in relation to the dispersion and scattering of light, Proc. R. Soc. Ser. 1, 104, 333-357, doi:10.1098/rspa.1923.0113.

Klett, J. D. (1985), Lidar inversion with variable backscatter/extinction ratios, Appl. Opt., 24, 1638-1643, doi:10.1364/AO.24.001638.

Krysta, M., and M. Bocquet (2007), Source reconstruction of an accidental radionuclide release at European scale, Q. J. R. Meteorol. Soc., 133, 529-544, doi:10.1002/qj.3.

Labazuy, P., M. Gouhier, A. Harris, Y. Guéhenneux, M. Hervo, P. Freville, J.-C. Bergès, P. Cacault, and S. Rivet (2012), Near real-time monitoring of the April-May 2010 Eyjafjallajökull ash cloud: An example of a web-based, satellite-data-driven, reporting system, Int. J. Environ. Pollut., in press.

McCormick, M. P., and R. E. Veiga (1992), SAGE II measurements of early Pinatubo aerosols, Geophys. Res. Lett., 19(2), 155-158, doi:10.1029 $91 \mathrm{GL} 02790$.

Measures, R. M. (1984), Laser Remote Sensing: Fundamentals and Applications, John Wiley, Hoboken, N. J.

Michalsky, J. J., B. M. Herman, and N. R. Larson (1984), Mid-latitude stratospheric aerosol layer enhancement by El Chichon: The first year, Geophys. Res. Lett., 11(1), 76-79, doi:10.1029/GL011i001p00076.

Mishchenko, M. I., and L. D. Travis (1998), Capabilities and limitations of a current FORTRAN implementation of the T-matrix method for randomly oriented, rotationally symmetric scatterers, J. Quant. Spectrosc. Radiat. Transfer, 60, 309-324, doi:10.1016/S0022-4073(98)00008-9.

Nicolet, M. (1984), On the molecular scattering in the terrestrial atmosphere, Planet. Space Sci., 32, 1467-1468, doi:10.1016/0032-0633(84)90089-8.

Niemeier, U., C. Timmreck, H.-F. Graf, S. Kinne, S. Rast, and S. Self (2009), Initial fate of fine ash and sulfur from large volcanic eruptions, Atmos. Chem. Phys., 9, 9043-9057, doi:10.5194/acp-9-9043-2009.

Powell, K. A., C. A. Hostetler, M. A. Vaughan, K.-P. Lee, C. R. Trepte, R. R. Rogers, and D. M. Winker (2009), CALIPSO lidar calibration algorithms: Part I - Nighttime $532 \mathrm{~nm}$ parallel channel and $532 \mathrm{~nm}$ perpendicular channel, J. Atmos. Oceanic Technol., 26, 2015-2033, doi:10.1175/2009JTECHA1242.1.

Prata, A. J. (1989), Infrared radiative transfer calculations for volcanic ash clouds, Geophys. Res. Lett., 16, 1293-1296, doi:10.1029/ GL016i011p01293.

Prata, A. J., and J. Kerkmann (2007), Simultaneous retrieval of volcanic ash and $\mathrm{SO}_{2}$ using MSG-SEVIRI measurements, Geophys. Res. Lett., 34, L05813, doi:10.1029/2006GL028691.

Quélo, D., M. Krysta, M. Bocquet, O. Isnard, Y. Minier, and B. Sportisse (2007), Validation of the Polyphemus platform on the ETEX, Chernobyl and Algeciras cases, Atmos. Environ., 41, 5300-5315, doi:10.1016/j. atmosenv.2007.02.035 
Randriamiarisoa, H., P. Chazette, P. Couvert, J. Sanak, and G. Mégie (2006), Relative humidity impact on aerosol parameters in a Paris suburban area, 1389-1407, Atmos. Chem. Phys., 6, 1389-1407, doi:10.5194/ acp-6-1389-2006.

Raut, J.-C., and P. Chazette (2007), Retrieval of aerosol complex refractive index from a synergy between lidar, sunphotometer and in situ measurements during LISAIR experiment, Atmos. Chem. Phys., 7, 2797-2815, doi:10.5194/acp-7-2797-2007.

Raut, J.-C., and P. Chazette (2008), Vertical profiles of urban aerosol complex refractive index in the frame of ESQUIF airborne measurements, Atmos. Chem. Phys., 8, 901-919, doi:10.5194/acp-8-901-2008.

Raut, J.-C., and P. Chazette (2009), Assessment of vertically resolved $\mathrm{PM}_{10}$ from mobile lidar observations, Atmos. Chem. Phys., 9, 8617-8638, doi:10.5194/acp-9-8617-2009.

Raut, J.-C., P. Chazette, and A. Fortain (2009a), Link between aerosol optical, microphysical and chemical measurements in an underground railway station in Paris, Atmos. Environ., 43, 575-583, doi:10.1016/j. atmosenv.2008.10.002.

Raut, J.-C., P. Chazette, and A. Fortain (2009b), New approach using lidar measurements to characterize spatiotemporal aerosol mass distribution in an underground railway station in Paris, Atmos. Environ., 43(3), 575-583, doi:10.1016/j.atmosenv.2008.10.002.

Royer, P., P. Chazette, M. Lardier, and L. Sauvage (2010a), Aerosol content survey by mini- $\mathrm{N}_{2}$-Raman lidar: Application to local and long-range transport aerosols, Atmos. Environ., 45(39) 7487-7495, doi:10.1016/j. atmosenv.2010.11.001.

Royer, P., J.-C. Raut, G. Ajello, S. Berthier, and P. Chazette (2010b), Synergy between CALIOP and MODIS instruments for aerosol monitoring: Application to the Po Valley, Atmos. Meas. Tech., 3, 893-907, doi:10.5194/amt-3-893-2010.

Sassen, K., J. Zhu, P. Webley, K. Dean, and P. Cobb (2007), Volcanic ash plume identification using polarization lidar: Augustine eruption, Alaska Geophys. Res. Lett., 34, L08803, doi:10.1029/2006GL027237.

Schumann, U., et al. (2011), Airborne observations of the Eyjafjalla volcano ash cloud over Europe during air space closure in April and May 2010, Atmos. Chem. Phys., 11, 2245-2279, 1doi:10.5194/acp11-2245-2010.

Searcy, C., K. Dean, and W. Stringer (1998), PUFF: A high-resolution volcanic ash tracking model, J. Volcanol. Geotherm. Res., 80, 1-16, doi:10.1016/S0377-0273(97)00037-1
Sigmundsson, F., et al. (2010), Intrusion triggering of the 2010 Eyjafjallajökull explosive eruption, Nature, 468, 426-430, doi:10.1038/nature09558.

Stohl, A., et al. (2011), Determination of time- and height-resolved volcanic ash emissions and their use for quantitative ash dispersion modeling: The 2010 Eyjafjallajökull eruption, Atmos. Chem. Phys., 11, 4333-4351, doi:10.5194/acp-11-4333-2011.

Tikhonov, A. E., and V. Y. Arsenin (1977), Solution of Ill-Posed Problems, John Wiley, Hoboken, N. J.

Tombette, M., P. Chazette, B. Sportisse, and Y. Roustan (2008), Simulation of aerosol optical properties over Europe with a 3D size-resolved aerosol model: Comparisons with AERONET data, Atmos. Chem. Phys., 8, 7115-7132, doi:10.5194/acp-8-7115-2008.

Troen, I. B., and L. Mahrt (1986), A simple model of the atmospheric boundary layer; sensitivity to surface evaporation, Boundary Layer Meteorol., 37, 129-148, doi:10.1007/BF00122760.

Wen, S., and W. I. Rose (1994), Retrieval of sizes and total masses of particles in volcanic clouds using AVHRR bands 4 and 5, J. Geophys Res., 99, 5421-5431, doi:10.1029/93JD03340.

Winker, D. M., W. H. Hunt, and C. A. Hostetler (2004), Status and performance of the CALIOP lidar, Proc. SPIE Int. Soc. Opt. Eng., 5575, 8-15, doi: $10.1117 / 12.571955$

Winker, D. M., W. H. Hunt, and M. J. McGill (2007), Initial performance assessment of CALIOP, Geophys. Res. Lett., 34, L19803, doi:10.1029/ 2007GL030135.

M. Bocquet and V. Winiarek, Université Paris-Est, CEREA, Joint Laboratory École des Ponts ParisTech and EDF R\&D, 6-8 Avenue Blaise Pascal, Cité Descartes Champs-sur-Marne, F-77455 Marne la Vallée, CEDEX 2, France.

J.-P. Cariou and M. Lardier, LEOSPHERE, 76 Rue de Monceau, F-75008 Paris, France.

P. Chazette and P. Royer, LSCE, CEA-CNRS-UVSQ, CEA Saclay, F-91191 Gif-sur-Yvette, France. (patrick.chazette@1sce.ipsl.fr)

M. Gouhier and P. Labazuy, OPGC/LMV, CNRS-IRD-UBP, 5 Rue Kessler, F-63038 Clermont-Ferrand, France.

J.-C. Raut, LATMOS, UPMC-UVSQ-CNRS, Université Paris 6, F-75252 Paris, France. 